NBER WORKING PAPER SERIES

THE RISE OF PASS-THROUGHS AND THE DECLINE OF THE LABOR SHARE

\author{
Matthew Smith \\ Danny Yagan \\ Owen M. Zidar \\ Eric Zwick \\ Working Paper 29400 \\ http://www.nber.org/papers/w29400 \\ NATIONAL BUREAU OF ECONOMIC RESEARCH \\ 1050 Massachusetts Avenue \\ Cambridge, MA 02138 \\ October 2021
}

We thank David Autor, Nick Bloom, Jediphi Cabal, Curtis Carlson, Michael Cooper, Bob Hall, Pete Klenow, Adam Looney, Jay MacKie, John McClelland, Brent Neiman, James Pearce, Jim Poterba, Rich Prisinzano, David Romer, and seminar and conference participants for helpful conversations on this draft. We thank Stephanie Kestelman, Dustin Swonder, Samuel WallachHanson, and Caleb Wroblewski for excellent research assistance. Zidar and Zwick gratefully acknowledge financial support from Chicago Booth's Initiative on Global Markets (IGM), the Kauffman Foundation, and the University of Chicago Booth School of Business. Zidar also gratefully acknowledges support from the Kathryn and Grant Swick Faculty Research Fund at the University of Chicago Booth School of Business and National Science Foundation under Grant Number 1752431, and Zwick gratefully acknowledges financial support from the Neubauer Family Foundation, the Polsky Center, and the Hultquist Faculty Research Endowment at the University of Chicago Booth School of Business. This work expresses the views of the authors themselves and does not necessarily reflect the views of the US Treasury Department, the Office of Management and Budget, the U.S. Government, or the National Bureau of Economic Research.

NBER working papers are circulated for discussion and comment purposes. They have not been peer-reviewed or been subject to the review by the NBER Board of Directors that accompanies official NBER publications.

(C) 2021 by Matthew Smith, Danny Yagan, Owen M. Zidar, and Eric Zwick. All rights reserved. Short sections of text, not to exceed two paragraphs, may be quoted without explicit permission provided that full credit, including $\odot$ notice, is given to the source. 
The Rise of Pass-Throughs and the Decline of the Labor Share

Matthew Smith, Danny Yagan, Owen M. Zidar, and Eric Zwick

NBER Working Paper No. 29400

October 2021

JEL No. E01,E25,H25,J32

\section{ABSTRACT}

This paper studies the coevolution of the fall in the US corporate sector labor share and the rise of business activity in tax-preferred, pass-through form. Reallocating activity to the form it would have taken prior to the Tax Reform Act of 1986 accounts for one third of the decline in the corporate sector labor share between 1978 and 2017. Our adjustments are concentrated among mid-market firms in services, leaving a larger role for the manufacturing sector and superstar firms in driving the remaining decline in the labor share. Our findings highlight the importance of tax policy when measuring factor shares.

Matthew Smith

Office of Tax Analysis

U.S. Department of the Treasury 1500 Pennsylvania Avenue, NW

Washington, D.C. 20220

matthew.smith@treasury.gov

Danny Yagan

Department of Economics

University of California, Berkeley

530 Evans Hall, \#3880

Berkeley, CA 94720

and NBER (on leave)

yagan@berkeley.edu
Owen M. Zidar

Department of Economics \&

School of International and Public Affairs

Princeton University

237 Julis Romo Rabinowitz Building

Princeton, NJ 08544

and NBER

ozidar@princeton.edu

Eric Zwick

Booth School of Business

University of Chicago

5807 South Woodlawn Avenue

Chicago, IL 60637

and NBER

ezwick@chicagobooth.edu 


\title{
The Rise of Pass-Throughs and the Decline of the Labor Share
}

\author{
Matthew Smith, Danny Yagan, Owen Zidar, and Eric Zwick*
}

October 13, 2021

\begin{abstract}
We study the coevolution of the fall in the U.S. corporate-sector labor share and the rise of business activity in tax-preferred pass-throughs. We find that reallocating activity to the form it would have taken prior to the Tax Reform Act of 1986 accounts for one third of the decline in the corporate-sector labor share between 1978 and 2017. Our adjustments are concentrated among mid-market firms in services, magnifying the role of the manufacturing sector and superstar firms in driving the remaining decline in the labor share. Our findings highlight the importance of tax policy when measuring factor shares.
\end{abstract}

In the past forty years in the United States, the share of corporate-sector value added accruing to labor in national accounts fell from $62.9 \%$ to $57.9 \%$ (Figure 1A). This period coincided with a striking rise in the share of business activity organized in "pass-through" form (Figure 1B). This paper shows that these trends are related.

Why would growth of the pass-through sector, which now accounts for the majority of business income, matter for the corporate-sector labor share? The simple answer is taxes. First, entrepreneurs have flexibility to characterize their income as labor payments or as

${ }^{*}$ Smith: US Treasury Department (email: matthew.smith@treasury.gov); Yagan, UC Berkeley and NBER (email: yagan@berkeley.edu); Zidar, Princeton and NBER (email: ozidar@princeton.edu); Zwick, Chicago Booth and NBER (email: ezwick@chicagobooth.edu). This work does not necessarily reflect the views of the US Treasury Department. We thank David Autor, Nick Bloom, Jediphi Cabal, Curtis Carlson, Michael Cooper, Bob Hall, Pete Klenow, Adam Looney, Jay MacKie, John McClelland, Brent Neiman, James Pearce, Jim Poterba, Rich Prisinzano, David Romer, and seminar and conference participants for helpful conversations on this draft. We thank Stephanie Kestelman, Dustin Swonder, Samuel WallachHanson, and Caleb Wroblewski for excellent research assistance. Zidar and Zwick gratefully acknowledge financial support from Chicago Booth's Initiative on Global Markets (IGM), the Kauffman Foundation, and the University of Chicago Booth School of Business. Zidar also gratefully acknowledges support from the Kathryn and Grant Swick Faculty Research Fund at the University of Chicago Booth School of Business and National Science Foundation under Grant Number 1752431, and Zwick gratefully acknowledges financial support from the Neubauer Family Foundation, the Polsky Center, and the Hultquist Faculty Research Endowment at the University of Chicago Booth School of Business. 
profits. They typically choose the label that minimizes taxes subject to the law. In recent years, that label has been profit for a growing number of firms. Second, the composition of corporate-sector firms has changed: many labor-intensive firms are now organized outside the corporate sector as tax-preferred partnerships. The joint quantitative importance of these factors for falling labor shares and rising capital shares is an open question with implications for the analysis of technological change, inequality, and tax policy.

The historical turning point for the rise of pass-throughs is the Tax Reform Act of 1986 (TRA86). TRA86 lowered personal income tax rates substantially and raised the tax burden on (non-pass-through) C-corporations. As a result, by organizing in pass-through form, entrepreneurs avoid C-corporation taxes and benefit from lower effective tax rates. Subsequent changes in payroll taxation and in the legal treatment of pass-throughs raised the benefits and feasibility of adopting pass-through form, accelerating the pace of this sector's growth.

We take two steps to quantify the contribution of the pass-through sector to the decline of the labor share. First, we reclassify a portion of S-corporation value added as labor income. Using data on 183,000 firms that switch from C-corporation to S-corporation form between 2000 and 2012, we estimate that reported labor payments fall sharply in the switching year by $2.29 \%$ of sales, which are offset by a corresponding increase in reported profits. Estimates that account for heterogeneous effects by firm size imply that $1.22 \%$ of aggregate S-corporation sales can be thought of as recharacterized labor payments.

This behavior implies the decline in labor payments captures a reporting response, as owner-managers compensate themselves in the tax-preferred form of S-corporation profits. Had these firms remained C-corporations, owner-managers would have likely continued to pay themselves via labor income to avoid payout and corporate tax. Reclassifying $1.22 \%$ of aggregate S-corporation sales increases the corporate-sector labor share by 0.89 percentage points in 2017.

Our second adjustment is to "reincorporate" partnership activity into the corporate sector. Since 1980, partnership net income has grown from $13 \%$ to $35 \%$ of total business profits. This rise occurred as the corporate sector in the national accounts shrank from $60 \%$ to $57 \%$ of GDP and the noncorporate business sector - which includes partnership activity - grew from $14 \%$ to $17 \%$ of GDP (Figure 1C). Partnership activity comprises mainly capital-light activity in the form of financial, legal, and consulting services. These businesses have higher labor shares than the businesses that have remained in corporate form. Treating these partnerships as C-corporations both reverses the recent decline of corporate-sector value added relative to GDP and increases the corporate-sector labor share by 0.79 percentage points in 2017.

Together, these two adjustments imply the 5.0-percentage-point decline in the labor share 
is overstated by $32 \%$. The extent of understated labor income has grown over time in line with the pass-through sector's expansion. In the 1990s, the growth of S-corporations accounts for most of this effect, whereas partnerships play a larger role in more recent years. All of the decline in our adjusted series occurred since the early 2000s.

More than half of the adjustment comes from skilled service firms in capital-light industries. Firms in these industries include law firms, consultancies, doctors' and dentists' offices, and financial service firms such as hedge funds and private equity funds. Such medium-sized firms account for a disproportionate share of pass-through value added, while large, capitalintensive manufacturers are more prominent as C-corporations (Figure 1D). By correcting for downward bias among mid-market service firms, our adjusted series implies a larger role for superstar firms and the manufacturing sector to drive the remaining decline in the labor share.

\section{Institutional Background and Data}

\section{A Institutional Background}

The way entrepreneurs report their income depends on tax rules. This section describes U.S. business taxes as of 2017. We focus on the three formal business types: C-corporations, S-corporations, and partnerships. C- and S-corporations are both in the corporate sector, whereas partnerships and sole proprietorships are not. We focus on formal business because sole proprietorships have not exhibited clear growth over the past forty years, and their role in labor-share measurement is studied elsewhere (Gollin, 2002; Elsby, Hobijn and Şahin, 2013).

C-corporations pay the corporate income tax; their taxable shareholders pay dividend taxes on distributed profits. C-corporations can retain earnings to delay the owner-level tax. In contrast, S-corporations do not pay corporate tax, and they cannot defer the distribution of profits, which are deemed distributed and taxable at the owner level when earned. The tax rate that applies to S-corporation profits is the individual income tax rate for each owner based on their share of firm profits.

Owner-managers have leeway in whether they report their income as wages or profits. TRA86 made S-corporation form tax superior to C-corporation form for eligible firms. Ever since, the S-corporation share of business activity has risen while the C-corporation share has fallen.

C-corporation owner-managers face tax incentives to report their income as wages while S-corporation owner-managers face tax incentives to report it as profits. Since wages are 
deductible, owner-managers of C-corporations can avoid the corporate tax plus dividend tax when they report their share of profits as wages. Their wage income faces personal income tax plus payroll and social insurance taxes. In contrast, S-corporation owner-managers do not pay payroll and social insurance taxes when they report their share of profits as business income.

In 2017, the tax rate for C-corporation profits was 35\% at the entity level and $15 \%$ to $23.8 \%$ (including the $3.8 \%$ surtax on net investment income) for taxable dividends depending on a taxpayer's income bracket. The top marginal income tax rate for wages was $39.6 \%$. The payroll tax rate was $12.4 \%$ for the first $\$ 118.5 \mathrm{~K}$ of wages. The more relevant marginal incentives for top earners were the uncapped social insurance taxes of $2.9 \%$ for Medicare and $0.9 \%$ for the Affordable Care Act. Thus, a high-income C-corporation ownermanager saved $7.1 \%-(35+.238 \times(100-35))-(39.6+3.8)$ - on the margin by paying herself as wages; a high-income S-corporation owner-manager saved $3.8 \%$ in payroll and social insurance taxes by paying herself in profits. Comparing corporate forms, the lowest rate for a C-corporation owner-manager was $43.4 \%$, which exceeded the $39.6 \%$ rate for an S-corporation owner-manager. This wedge encouraged firms to organize as S-corporations and label owner-manager income as profits. ${ }^{1}$

A related change in the organization of business activity is the growth of partnerships. Following TRA86 and state law changes permitting partnerships to receive limited liability protection, many firms that might have otherwise chosen C-corporation form instead organized as partnerships. This option appeals especially to firms, such as large law firms and consultancies with too many owners to receive pass-through tax treatment as S-corporations, and financial firms that have non-individual investors as limited partners. Unlike the case of S-corporations, owner-managers of partnerships receive little pay as wages. Instead, their compensation is ordinary business income (i.e., profits) and guaranteed payments, both of which enter the national accounts as proprietors' income in the noncorporate business sector. The tax treatment of this compensation can allow partners to avoid payroll and social insurance taxes just like in S-corporations (OTA, 2016).

\section{B Data}

Administrative tax data. Our event studies use de-identified administrative tax data from 1996 to 2016 for the population of C-corporations and S-corporations. We use a sample of firms that switch from C-corporation to S-corporation form between 2000 and 2012, which

\footnotetext{
${ }^{1}$ S-corporation owner-manager compensation is required to be "reasonable" and reflect the value of market services. In practice, the IRS rarely adjusts S-corporation owner tax liabilities (Auten, Splinter and Nelson, 2016; Nelson, 2016).
} 
allows us to study outcomes in a four-year window around the switching event. During this time, the number of firms switching each year is approximately 15,000, cumulatively accounting for nearly $10 \%$ of all C-corporations in 2000. The outcome variable in the event studies is Labor payments, which equals Salaries and wages plus Compensation of officers, Pension and profit-sharing contributions, and Benefit programs, as listed on the business income tax return.

Following Smith et al. (2019), we link S-corporations and individual-owned partnerships to their owners for 2001-2014 by merging firm-level business income tax returns onto firm information returns that identify owners. We then merge on each owner's fiscal income and W-2 wage payments. We use this population of linked owner-firm data to compute Owner pay, which combines wages and ordinary business income paid to owners, at the industry and firm-size levels. We supplement these population-level data with the Integrated Business Data aggregates from the Statistics of Income (SOI) samples from 1980 to 2015, as well as other public aggregates for all business forms. We produce additional collapses from the restricted-use SOI corporate and partnership samples covering the years 1992 to 2017 and 1987 to 2017, respectively. Appendix A describes these supplemental data and how we use them.

Macroeconomic data. Aggregate data on corporate- and noncorporate-sector value added and labor compensation come from NIPA. Gross value added of corporate business is from Table 1.14, line 1. Corporate sector compensation of employees is from Table 1.14, line 4. US GDP comes from Table 1.1.5, line 1.

Noncorporate-sector value-added components come from Table 1.13. National income for sole proprietors and partnerships is from Table 1.13, line 19. Compensation of workers within this sector is line 20. Proprietors' income is line 23. This table uses a national income, net of depreciation, concept to measure sectoral activity within and outside the corporate sector. We supplement this table with depreciation information for sole proprietorships and partnerships from Table 7.5, line 8, to derive a gross value added concept comparable to the concept for the corporate sector.

\section{Pass-Throughs and Recharacterized Labor Payments}

\section{A S-corporations}

Our goal is to estimate how much S-corporation owner pay would take the form of wages if S-corporations were C-corporations. Following Smith et al. (2019), we estimate how wages 
and profits evolve after a firm's choice to reorganize from C-corporation to S-corporation form with an event study:

$$
Y_{i t}=\sum_{k \in\{-5+,-4,-3,-2,0,1,2,3,4,5+\}} \gamma_{k} \mathbf{1}(t=k)+\alpha_{i}+\delta_{t}+\varepsilon_{i t},
$$

where $Y_{i t}$ is total wage payments or profits divided by contemporaneous firm sales, $\gamma_{k}$ are the coefficients of interest on event time indicators, $\alpha_{i}$ are firm fixed effects, and $\delta_{t}$ are calendar-year fixed effects. The analysis sample includes $183 \mathrm{~K}$ firms that switch corporate form between 2000 and 2012, that have maximum sales greater than $\$ 100,000$ in 2014 dollars, and that exist for at least 4 years before and after the switch event. Appendix B provides summary statistics.

As in Smith et al. (2019), a nontrivial share of S-corporation profits would have been reported as labor payments if the firms organized as C-corporations. For all firms in our sample, over $2 \%$ of sales are suddenly paid as profits instead of wages upon switching. We interpret the immediate divergence in both profits and labor payments to reflect recharacterized wages rather than technological changes around the switch. ${ }^{2}$

To map micro estimates to aggregate quantities, we depart from Smith et al. (2019) and estimate heterogeneous impacts by firm size. Figure $2 \mathrm{~A}$ estimates the effects on labor payments for firms divided into groups based on mean firm sales. We partition firms based on mean sales with boundaries at $\$ 100 \mathrm{~K}, \$ 500 \mathrm{~K}, \$ 1 \mathrm{M}, \$ 10 \mathrm{M}$, and $\$ 100 \mathrm{M}$ in 2014 dollars. Scope for relabeled labor income is greater among smaller firms, as effect sizes monotonically decrease with firm size. Effect sizes exceed $2 \%$ of sales even among firms with $\$ 1 \mathrm{M}$ to $\$ 10 \mathrm{M}$ in sales and are meaningful (1.1\% of sales) for firms in the $\$ 10 \mathrm{M}$ to $\$ 100 \mathrm{M}$ size group. Only the largest firms show no relabeling response upon switching. ${ }^{3}$ Other variables do not experience major declines following switching events (Appendix B).

Among S-corporations, mid-market firms account for a substantial share of aggregate activity. Firms with less than $\$ 10 \mathrm{M}$ and firms with $\$ 10 \mathrm{M}$ to $\$ 100 \mathrm{M}$ in average sales respectively account for $51 \%$ and $30 \%$ of total S-corporation value added, $38 \%$ and $34 \%$ of total sales, and $65 \%$ and $25 \%$ of total owner pay in the most recent available years (Figure $2 \mathrm{~B}$ ).

\footnotetext{
${ }^{2}$ Appendix Figure A.1A presents a plot showing the immediate divergence between profits and wages in the switching year. Appendix Table A.4 presents regression estimates and alternative specifications. We estimate effects relative to firm sales rather than measures of value added to minimize the impact of accounting changes on the scaling variable and to permit loss firms to enter the sample. Our homogeneous estimates differ slightly from Smith et al. (2019) because we use a longer sample and broaden the definition of wage payments using new data.

${ }^{3}$ Appendix Figure A.1B plots effects for the five largest industries in terms of S-corporation profits in 2017. Each industry shows a large decline in labor payments after switching, though firms in white-collar services show larger effects.
} 
To transform these event studies into a post-switch estimate of recharacterized wages, define $\bar{\gamma}$ to be the average of $\gamma_{k}$ for the post period $k \in 0,1,2,3,4$ where the outcome is total wage payments relative to firm sales. We report two averages: $\bar{\gamma}_{E}$ and $\bar{\gamma}_{S}$ for equal and size weights, respectively. We estimate $\bar{\gamma}_{E}$ to be $2.44 \%$ of sales. To account for heterogeneity by firm size, we estimate a variant of (1) that permits $\gamma_{k}$ to differ by firm size. Specifically, we estimate

$$
Y_{i t}=\sum_{k \in\{-5+,-4,-3,-2,0,1,2,3,4,5+\}} \sum_{b} \gamma_{b, k} \mathbf{1}(t=k, i \in b)+a_{i}+d_{t}+e_{i t},
$$

where $b$ corresponds to a sales bin (defined as in Figure 2A), $a_{i}$ are firm fixed effects, and $d_{t}$ are calendar-year fixed effects. If we estimate the average post-period effect $\bar{\gamma}_{b}$ at the size-bin level and compute the weighted average using size-group level, S-corporation sales in 2017 as weights, the estimate for $\bar{\gamma}_{S}$ is $1.22 \%$ of sales.

The lower size-weighted estimate follows from larger firms having smaller declines in labor compensation as a share of their sales. This empirical feature is important for applying these estimates to study aggregate quantities. Accordingly, we use the size-bin-specific estimates to ask how much S-corporation activity would be recorded as labor income within the corporate sector if all S-corporations were instead C-corporations. We use the estimates 3.25\%, 2.61\%, $2.12 \%$, and $1.09 \%$ for the respective size groups in Figure 2 (excluding the top group). Because S-corporation profits cannot be more than $100 \%$ capital income and because the largest bin's confidence intervals are positive but include zero, we set the coefficient for the largest bin $\bar{\gamma}_{100 \mathrm{M}+}$ equal to zero. Thus, in our adjustment, S-corporation profits among firms with sales greater than $\$ 100 \mathrm{M}$ are entirely capital. We make the same assumption for firms with less than $\$ 100 \mathrm{~K}$ in sales, which can be financial conduits and account for a minimal share of aggregate revenues and profits.

We draw on linked owner-firm data for S-corporations from 2001 to 2014 and use the size-bin-specific $\bar{\gamma}_{b}$ 's to construct an implied labor share for S-corporation owners $\omega_{b, t}^{S}$ :

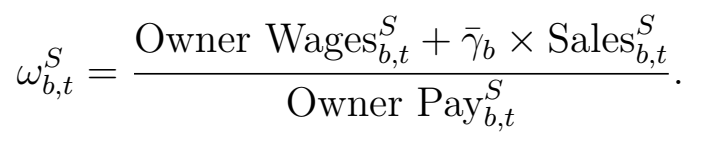

Here, $\bar{\gamma}_{b} \times \operatorname{Sales}_{b, t}^{S}$ represents the contribution of recharacterized wages for owners to the labor share. In 2014, applying (3) delivers $\omega_{b, 2014}^{S}$ equal to $62.5 \%, 63.4 \%, 58.9 \%, 47.5 \%$, and $15.2 \%$ for the respective size groups in Figure 2B. 


\section{B Recharacterized Wages in Partnerships}

Unlike S-corporations, partnerships do not face reasonable compensation rules and instead compensate owner-managers via profit distributions. To construct a concept of labor share for partnership owners, we develop an estimate in a consistent fashion to the estimate from S-corporations. The goal is to estimate how much owner pay would take the form of wages if partnerships were C-corporations.

We assume the share of owner pay (i.e., wages plus profits) that partnerships would report as wages equals the share for similarly-sized S-corporations, i.e., we assume $\omega_{b, t}^{P}=\omega_{b, t}^{S}$. We then use linked owner-firm data for partnerships to construct size-bin shares of owner pay from the partnership sector each year. These size-bin shares serve as weights for computing an aggregate labor share $\omega_{t}^{P}$ for partnership owners in year $t$.

In 2014, we estimate a labor share of owner pay $\omega_{t}^{P}$ equal to $41.9 \%$. Large firms account for a larger share of owner pay among partnerships (Figures $2 \mathrm{~B}$ and $2 \mathrm{C}$ ), so this figure is lower than the analog for S-corporations. During the period when our linked owner-firm data are available, $\omega_{t}^{P}$ falls from $55.9 \%$ in 2001 to $41.9 \%$ in 2014, which reflects the entry of larger firms into the partnership sector over time. ${ }^{4}$

\section{Labor Shares after Pass-Through Adjustments}

\section{A S-corporations}

How much would the corporate-sector labor share have declined if all S-corporations were C-corporations? To answer this question, we recompute the corporate-sector labor share after adding S-corporation recharacterized wages to the numerator, leaving the denominator unchanged. For each firm-size bin and year, S-corporation recharacterized wages equal the size-bin-specific $\bar{\gamma}_{b}$ from Section A multiplied by sales in that bin. In 2017, we estimate that $\$ 99 \mathrm{~B}$ of aggregate $\mathrm{S}-$ corporation profits are recharacterized wages. Table 1 provides a simple way to understand the $\$ 99 \mathrm{~B}$ estimate. In 2017 , aggregate S-corporation sales equal $\$ 8.12 \mathrm{~T}$ and the 2017-sales-bin-weighted mean of $\bar{\gamma}_{b}$ equals $1.22 \%$. Their product equals $\$ 99 \mathrm{~B}$.

Accounting for S-corporation recharacterized wages, the aggregate labor share in 2017 is understated by 0.89 percentage points. How important is this adjustment for the decline in the labor share? The labor share fell from $62.9 \%$ in 1978 to $57.9 \%$ in 2017 , equal to 5.0 percentage points. Hence, our adjustment implies that $17.7 \%$ of the decline in the corporate labor share is due to tax-motivated growth of S-corporations.

\footnotetext{
${ }^{4}$ We use $55.9 \%$ for years prior to 2001 and $41.9 \%$ for years after 2014 .
} 
Figure 3A displays the results for the full time series. The S-corporation adjustment opens up immediately after TRA86, consistent with research documenting immediate adjustments for many firms (Feenberg and Poterba, 1993; Gordon and Slemrod, 2000). The adjustment widens modestly over time. Two factors explain why this widening is less pronounced than the overall growth of pass-through firms. First, as ownership rules for S-corporations relaxed, larger and more capital-intensive S-corporations account for a growing share of activity. Thus, in later years, more activity falls into size bins where we estimate lower recharacterizedwage shares. Second, as partnership form became more flexible and legally substitutable for corporate form in the 1990s, growth in the pass-through sector shifted from S-corporations to partnerships.

\section{B Partnerships}

We now estimate a counterfactual labor share in the case where tax-motivated growth of partnerships would have instead occurred in C-corporation form. Reincorporating partnerships requires a few considerations that complicate the calculation relative to the case of S-corporations. First, because the national accounts do not separate sole proprietorships and partnerships, we need to remove sole proprietors from aggregate series. Second, there existed a baseline level of partnership activity prior to TRA86. We want to exclude these partnerships from our exercise to focus on partnership growth that is likely to be tax-motivated.

Table 1C walks through our computation in steps for 2017. The first step is to isolate partnerships in the sole-proprietorships-and-partnership value added series from the BEA. This series relies on partnership and sole proprietor tax filings plus adjustments to align definitions with national income concepts. ${ }^{5}$

In 2017, gross value added for sole proprietorships and partnerships is $\$ 3.29 \mathrm{~T}$. Gross value added equals the sum of three components: (1) labor compensation is $\$ 1.13 \mathrm{~T}$; (2) proprietors' income (i.e., non-W2 payments to sole proprietors and partners) accounts for $\$ 1.50 \mathrm{~T}$; and (3) rental income, net interest, and depreciation account for $\$ 0.66 \mathrm{~T}$. To estimate each component of gross value added for partnerships, we use the partnership share of the analogous component from SOI aggregates for sole proprietorships and partnerships. For example, in 2017 partnerships generated $82.2 \%, 72.30 \%$, and $81.5 \%$ of combined partnership and sole proprietorship employee compensation, proprietors' income, and other capital income, respectively. ${ }^{6}$

\footnotetext{
${ }^{5}$ The largest adjustments in the BEA series include misreporting, reducing payments to corporate partners that appear in the corporate sector's account, and reducing partnership payments for payments made to other partnerships that would otherwise be double-counted. Pearce (2015) and Cooper et al. (2016) discuss how tiered partnerships complicate measurement of aggregate partnership income.

${ }^{6}$ For proprietors' income, we use aggregate sole proprietorship and partnership proprietors' income from
} 
For 2017, we therefore allocate these respective shares of each component of sole-proprietorshipand-partnership gross value added to partnerships. We compute this allocation share each year to account for different growth rates between the partnership and sole proprietorship sectors and among components.

The second step is to compute a baseline level of partnership value added that we assume would have remained outside the corporate sector. We set this baseline to be the 1986 level of partnership value added as a share of GDP. By construction, this assumption ensures there is no difference between the adjusted and unadjusted corporate sector amounts in 1986 and before. Subsequently, as the noncorporate sector grows relative to GDP and the partnership sector grows relative to the sole proprietorship sector, the amount of partnership activity to be reincorporated increases. We compute baseline 1986 shares of GDP component-bycomponent because labor compensation and proprietors' income have grown faster than other capital income within gross value added.

The third step is to compute excess partnership value added by subtracting the 1986 baseline from actual partnership value added. In 2017, the amount of employee compensation attributed to partnerships is $\$ 925 \mathrm{~B}(=82.2 \% \times \$ 1.13 T)$. Baseline 1986 employee compensation in partnerships as a share of GDP is $2.0 \%$, which yields a baseline level of $\$ 396 \mathrm{~B}$. Hence, we estimate the excess employee compensation is $\$ 529 \mathrm{~B}(=\$ 925 B-\$ 396 B)$. The analogous excess amounts for proprietors' income and other capital income are $\$ 469 \mathrm{~B}$ and $\$ 73 \mathrm{~B}$.

The fourth step is to decompose the components of excess value added into labor and capital. Employee compensation and other capital income are 100\% labor and 100\% capital, respectively. For proprietors' income, we use the labor share of owner pay $\omega_{t}^{P}$ from Section B. In 2017, $\omega_{t}^{P}$ equals $41.9 \% .^{7}$

In the final step, we estimate the corporate-sector labor share after reincorporating partnership activity that exceeds its 1986 level. In particular, we add excess employee compensation and the labor share of proprietors' income to the numerator of the corporate-sector labor share. We add all three excess partnership components, which sum to excess partnership value added, to the denominator.

The last lines of Table $1 \mathrm{C}$ report the results for 2017. The sum of excess partnership profits and W2 wages paid to partners is $\$ 485 \mathrm{~B}(\approx \$ 469 B+17 B)$. Multiplying this amount by $41.9 \%$ yields $\$ 204 \mathrm{~B}$ of labor compensation to partners. We then subtract the $\$ 17 \mathrm{~B}$ in

NIPA to avoid double-counting profits in the partnership sector. See Appendix C for details.

${ }^{7}$ Before applying $\omega_{t}^{P}$, we add wages paid to partners from our linked data, which is small relative to owner pay for partnerships ( $\$ 17 \mathrm{~B}$ in 2017). Our baseline $\omega_{t}^{P}$ might be conservative. For example, Piketty, Saez and Zucman (2018) assume the labor share of proprietors' income is $70 \%$. We consider less conservative assumptions in Table 2 . 
W2 wages paid to partners, which are included in the employee compensation category, to obtain our estimate of $\$ 187 \mathrm{~B}$ for partnership recharacterized wages.

In 2017, our adjustment adds $\$ 716 \mathrm{~B}(\approx \$ 529 B+\$ 187 B)$ of partnership labor income and $\$ 1.07 \mathrm{~T}(\approx \$ 529 B+\$ 469 B+\$ 73 B)$ of partnership value added to the corporate sector. As a result, we estimate that the aggregate corporate labor share is understated by 0.79 percentage points due to tax-motivated migration of relatively labor-intensive business activity from Ccorporation form into the noncorporate sector. Relative to the 5.0 percentage-point decline of the raw series, our 0.79-percentage-point partnership adjustment explains $15.8 \%$ of the corporate-sector labor share decline.

Figure 3B displays the full time series of results for our partnership adjustment. The graph shows that the partnership adjustment makes little difference until the late 1990s. In recent years, the labor share in the partnership sector exceeds the labor share in the corporate sector by more than ten percentage points. For example, in 2017 the implied labor share for reincorporated activity is $66.9 \%(=\$ 715 B / \$ 1.07 T)$.

This fact reflects compositional differences across corporate form. Partnerships are now predominantly service-sector firms, such as law firms, consultancies, and financial services, whereas the corporate sector includes more capital-intensive activity in manufacturing and trade, especially among C-corporations. This evolution can be seen in the surge of proprietors' income relative to interest, taxes, and depreciation, which matches the rise in partnership profits since the 1990s. The time series closely follows state-level legal reforms that extended limited liability to partnerships and the 2001 tax cuts that increased the tax advantage of pass-throughs.

\section{Overall Effect of Pass-Through Growth on the Labor Share}

Figure 3C and Table 1A-B combine the S-corporation and partnership adjustments. Over the 1978-2017 period, our corporate labor share series after both adjustments shows a decline of 3.4 percentage points, $31.9 \%$ (1.6pp) smaller than the 5.0 percentage point decline in the raw BEA data. Instead of the corporate labor share declining from $62.9 \%$ in 1978 to $57.9 \%$ in 2017, our adjusted labor share declined from $62.9 \%$ to $59.5 \%$ in $2017 .{ }^{8}$ Because our S-corporation adjustment primarily affects the pre-2000 series, our partnership adjustment contributes more to flattening the recent downward trend.

By increasing the share of economic activity in the corporate sector, our adjustment

\footnotetext{
${ }^{8}$ Appendix Table A.5 shows this result is robust to different start and end points by comparing the five-year average of 1978-1982 versus 2013-2017. Note the overall effect (1.6pp) differs from the sum of the individual efffects $(0.9 \mathrm{pp}$ and $0.8 \mathrm{pp})$ because the partnership adjustment increases the denominator. Appendix Figure A.4 applies these adjustments to the overall labor share.
} 
also alters the trend in corporate gross value added relative to GDP. Instead of flattening and declining since the 1980s, the series continues the trend extending back to the 1950s of increasing corporate activity. In 2017, adjusted corporate sector value added is $62.3 \%$ of GDP, instead of $56.8 \%$ in the unadjusted series (Appendix Figure A.3).

Appendix Table A.1 decomposes the adjustment into contributions by three-digit industry for 2017. The three most important are Professional, Scientific, and Technical Services; Outpatient Healthcare; and Other Financial Services, which respectively contribute 27\%, $14 \%$, and $11 \%$ of the labor share adjustment. Thus, more than half of the adjustment comes from skilled-service firms in capital-light industries.

Table 2 explores the robustness of our adjusted corporate labor share (see Appendix C for details). One concern is that our analysis relies on estimates from the population of non-random corporate form switchers. ${ }^{9}$ To address this concern, we consider alternative recharacterized-wages estimates and changes to the event study specification. We also consider a version of the partnership adjustment that allows the largest partnerships - which include consultancies, law firms, accountancies, and financial service firms that clearly provide human-capital services compenstated via nonwage income - to have nonzero recharacterized wages. Across sensitivity analyses, we find that the tax-motivated growth in pass-throughs explains between $26.8 \%$ and $40.4 \%$ of the decline in the corporate labor share.

To be clear, our empirical argument is (a) an increasing share of corporate activity is occurring in pass-through form rather than C-corporation form; and (b) pass-through ownermanagers pay themselves less in wages and more in profits for tax purposes. The legal services industry (NAICS 5411) offers a striking example of these dynamics (Appendix Figure A.5). Between 1994 and 2016, the total number of law firms increased steadily. Nearly all of this growth came via S-corporations, which rose from $25 \mathrm{~K}$ to $113 \mathrm{~K}$. In contrast, the number of C-corporations declined. In terms of activity shares, C-corporations initially accounted for $75.9 \%$ of corporate receipts, which steadily declined to $33.0 \%$. Even in the early 1990s, when C-corporations accounted for the majority of corporate receipts, these firms accounted for less than $20 \%$ of law firm profits. Instead, firm surplus was distributed as wages to avoid payout tax for owners. The evolution of law firms toward pass-through form implies that income once characterized as corporate-sector wages now appears as S-corporation profits or noncorporate partnership income. ${ }^{10}$

\footnotetext{
${ }^{9}$ We may overstate recharacterized wages if these firms are most likely to benefit from switching. However, auditing firms with prior tax returns as C-corporations for aggressive recharacterization would be relatively easy compared to auditing new firms. We may therefore understate the extent of recharacterized wages if these firms tend to be conservative tax planners.

${ }^{10}$ While there are relatively few law firm partnerships, these firms are large within the industry. Including partnership receipts, C-corporations account for less than $20 \%$ of total receipts in 2014.
} 
The recharacterized-wage share of pass-through income is lower than the estimate of the human-capital share of pass-through income implied by the owner-death and ownerretirement estimates of Smith et al. (2019). This broader concept of human capital includes, for example, returns to sweat equity (Bhandari and McGrattan, 2021) or spillovers due to firm-level productivity effects of owner-managers (Jäger and Heining, 2019; Choi et al., 2021). Regarding recharacterized wages, in firms with active and passive owners, agency frictions that encourage incentive pay structures likely prevent some C-corporations from distributing all profits as wages. IRS rules may also discourage this behavior. Indeed, Smith et al. (2019) find that wage and profit responses to corporate-form switches are smaller when firms do not have a majority owner. Such frictions would not affect estimates of the human-capital share of a pass-through firm's income, despite reducing the share of pass-through income that would appear as wages if the firm were a C-corporation. The latter is key to answering this paper's central question: how much would the BEA's measured labor share change if pass-through firms were instead C-corporations?

\section{Conclusion}

Our key finding is that adjusting for pass-through growth raises the 2017 corporate-sector labor share by 1.6 percentage points and implies the 1978-2017 decline is overstated by $31.9 \%$. While our emphasis on pass-throughs does not preclude the importance of other mechanisms, it does provide new evidence that can help guide future investigation.

We draw five lessons from our analysis. First, all of the decline in our adjusted series occurred since the early 2000s. Many studies do not focus on mechanisms that strengthened in the 2000s, but there are prominent exceptions. Autor et al. (2020) (henceforth ADKPV) find that, in manufacturing, transportation, and wholesale trade, concentration rose especially strongly since 2000, and they connect rising concentration to falling labor shares. Barkai (2020) finds evidence of rising markups in the 2000s. Autor and Salomons (2018) emphasize a rise in labor-substituting technology since the 1980s, note the acceleration in the labor share's decline since 2000, but do not argue technology can account for the acceleration.

Second, ADKPV emphasize the role of superstar firms. Our findings adjust mid-market firms more than large firms, yielding a larger contribution of the biggest firms to the labor share's decline. Thus, in terms of timing and the firm size distribution, our results reinforce the role played by superstar firms in the labor share decline.

Third, our results reflect the rise of the skilled service sector (Buera and Kaboski, 2012) and the tendency of service-sector firms to elect pass-through form and optimize payments to owners in response to taxes. In contrast, trends in manufacturing drive most of the overall 
decline in the economy-wide labor share. ${ }^{11}$ Labor share growth in the services sector is higher with our adjustment, further underscoring the role of manufacturing for the overall decline. Elsby, Hobijn and Şahin (2013); Karabarbounis and Neiman (2014); Acemoglu and Restrepo (2020); Kehrig and Vincent (2018); and Charles, Hurst and Schwartz (2019) stress mechanisms affecting manufacturing: offshoring, investment prices, robots, hyperproductive establishments, and skill mismatch, respectively.

Fourth, our analysis concerns tax factors that may be unique to the U.S. A natural question concerns whether we can draw lessons for international patterns. Capital taxes have fallen more than labor income taxes across many economies (Auerbach, 2006), so the general idea could apply elsewhere. In other countries, one commonly sees deferral of compensation among private businesses, either as retained earnings or generous life insurance and pensions (Kopczuk and Zwick, 2020). These forces could affect the labor share in Europe.

While Karabarbounis and Neiman (2014) document declines in several countries, the evidence on the global decline reveals significant heterogeneity and large outliers. ${ }^{12}$ Separately, Gutiérrez and Piton (2020) argue that the decline outside the U.S. is not robust. They focus on the inclusion of self-employed income and real estate in the corporate sector in other countries and how these components bias the labor share toward a downward trend. ${ }^{13}$ Thus, cross-country heterogeneity leaves room for a U.S.-specific story for a sharp decline in the U.S. corporate-sector labor share.

Last, our work complements recent studies on the effect of taxes on macroeconomic measurement. These forces operate mainly within large public and manufacturing companies that prevail as C-corporations. Guvenen et al. (2017) find that transfer pricing arrangements distort the balance of payments, as profits are shifted overseas to avoid U.S. corporate taxation. Tørsløv, Wier and Zucman (2020) find that U.S. multinationals shift profits to tax havens and avoid repatriating them, and this shifting has grown over time. Both transfer pricing and profit shifting may lead the corporate-sector labor share to be overstated. Koh, Santaeulàlia-Llopis and Zheng (2020) find that the change in treatment of intellectual property products in the national accounts flattens the pre-2000 decline in the labor share,

\footnotetext{
${ }^{11}$ Following Elsby, Hobijn and Şahin (2013), we decompose the official series into broad industries (Appendix Figure A.6). The contribution from manufacturing to the decline is 7.5 percentage points, which was offset by the rise in services. Without the manufacturing decline, the aggregate labor share would have risen 3.8 points.

${ }^{12}$ In EUKLEMS data from 1987 to 2011, three of the largest European economies - the U.K., France, and Italy - do not show declines (Appendix Figure A.7). The U.S. shows a larger decline than all European countries except Norway, an economy 3\% the size of the U.S. From 1995 to 2011, Scandinavian countries experience declines, as do most former Soviet Socialist Republics (perhaps including East Germany's contribution to the German trend). Drawing strong conclusions from these smaller economies and those undergoing transition from communism to capitalism is hard.

${ }^{13}$ Rognlie (2016) also cites increasing housing costs, but does not focus on the corporate sector.
} 
leaving a substantial decline that our revised series also shows.

Following the 2017 tax reform, firms face new incentives to select the tax-minimizing corporate form and owner-manager compensation due to, for example, the lower C-corporation tax rate and the qualified business income deduction for pass-through firms. As these incentives are understood, investigating future trends in the labor share will require grappling with the nuances of the tax code. 


\section{References}

Acemoglu, Daron, and Pascual Restrepo. 2020. "Robots and Jobs: Evidence from US labor markets." Journal of Political Economy, 128(6): 2188-2244.

Auerbach, Alan J. 2006. "The Future of Capital Income Taxation." Fiscal Studies, 27(4): 399-420.

Auten, Gerald, David Splinter, and Susan Nelson. 2016. "Reactions of High-Income Taxpayers to Major Tax Legislation." National Tax Journal, 69(4): 935-964.

Autor, David, and Anna Salomons. 2018. "Is Automation Labor Share-Displacing? Productivity Growth, Employment, and the Labor Share." Brookings Papers on Economic Activity, 2018(1): 1-87.

Autor, David, David Dorn, Lawrence F. Katz, Christina Patterson, and John Van Reenen. 2020. "The Fall of the Labor Share and the Rise of Superstar Firms." Quarterly Journal of Economics, 135(2): 645-709.

Azmat, Ghazala, and Rosa Ferrer. 2017. "Gender Gaps in Performance: Evidence from Young Lawyers." Journal of Political Economy, 125(5): 1306-1355.

Barkai, Simcha. 2020. "Declining Labor and Capital Shares." Journal of Finance, 75(5): 2421-2463.

Bhandari, Anmol, and Ellen McGrattan. 2021. "Sweat Equity in US Private Business." Quarterly Journal of Economics, 136(2): 727-781.

Buera, Francisco J., and Joseph P. Kaboski. 2012. "The Rise of the Service Economy." American Economic Review, 102(6): 2540-2569.

Charles, Kerwin Kofi, Erik Hurst, and Mariel Schwartz. 2019. "The Transformation of Manufacturing and the Decline in US Employment." NBER Macroeconomics Annual, 33(1): 307-372.

Choi, Joonkyu, Nathan Goldschlag, John C. Haltiwanger, and J. Daniel Kim. 2021. "Founding Teams and Startup Performance." NBER Working Paper No. 28417.

Cooper, Michael, John McClelland, James Pearce, Richard Prisinzano, Joseph Sullivan, Danny Yagan, Owen Zidar, and Eric Zwick. 2016. "Business in the United States: Who Owns It, and How Much Tax Do They Pay?" Tax Policy and the Economy, 30(1): 91-128.

Elsby, Michael W.L., Bart Hobijn, and Ayşegül Şahin. 2013. "The Decline of the U.S. Labor Share." Brookings Papers on Economic Activity, 2013(2): 1-63.

Feenberg, Daniel, and James Poterba. 1993. "Income Inequality and the Incomes of Very High-Income Taxpayers: Evidence from Tax Returns." Tax Policy and the Economy, 7: $145-177$. 
Fleck, Susan, Steven Rosenthal, Matthew Russell, Erich H. Strassner, and Lisa Usher. 2014. "A Prototype BEA/BLS Industry-Level Production Account for the United States." In Measuring Economic Sustainability and Progress. 323-372. University of Chicago Press.

Gollin, Douglas. 2002. "Getting Income Shares Right." Journal of Political Economy, 110(2): 458-474.

Gordon, Roger, and Joel Slemrod. 2000. "Are 'Real' Responses to Taxes Simply Income Shifting between Corporate and Personal Tax Bases?" In Does Atlas Shrug? The Economic Consequences of Taxing the Rich. , ed. Joel Slemrod, Chapter 8, 240-288. Cambridge, MA:Russell Sage Foundation Books at Harvard University Press.

Gutiérrez, Germán, and Sophie Piton. 2020. "Revisiting the Global Decline of the (Non-Housing) Labor Share." American Economic Review: Insights, 2(3): 321-338.

Guvenen, Fatih, Raymond J. Mataloni Jr, Dylan G. Rassier, and Kim J. Ruhl. 2017. "Offshore Profit Shifting and Domestic Productivity Measurement." NBER Working Paper No. 23324.

Jäger, Simon, and Jörg Heining. 2019. "How Substitutable are Workers? Evidence from Worker Deaths." MIT Working Paper.

Kaplan, Steven N., and Joshua Rauh. 2010. "Wall Street and Main Street: What contributes to the rise in the highest incomes?" Review of Financial Studies, 23(3): 10041050 .

Karabarbounis, Loukas, and Brent Neiman. 2014. "The Global Decline of the Labor Share." Quarterly Journal of Economics, 129(1): 61-103.

Kehrig, Matthias, and Nicolas Vincent. 2018. "Growing Productivity without Growing Wages: The Micro-Level Anatomy of the Aggregate Labor Share Decline." ERID Working Paper No. 244.

Koh, Dongya, Raül Santaeulàlia-Llopis, and Yu Zheng. 2020. "Labor Share Decline and Intellectual Property Products Capital." Econometrica, 88(6): 2609-2628.

Kopczuk, Wojciech, and Eric Zwick. 2020. "Business Incomes at the Top." Journal of Economic Perspectives, 34(4): 27-51.

Nelson, Susan C. 2016. "Paying Themselves: S Corporation Owners and Trends in S Corporation Income, 1980-2013." OTA Working Paper 107.

OTA. 2016. "Gaps betewen the Net Investment Income Tax Base and the Employment Tax Base." Office of Tax Analysis, U.S. Department of the Treasury, Washington, DC.

Pearce, James. 2015. "Measuring Aggregate Business Income with Tax Data." National Tax Journal, 68(4): 1025-1046. 
Piketty, Thomas, Emmanuel Saez, and Gabriel Zucman. 2018. "Distributional National Accounts: Methods and Estimates for the United States." Quarterly Journal of Economics, 133(2): 553-609.

Rognlie, Matthew. 2016. "Deciphering the Fall and Rise in the Net Capital Share: Accumulation or Scarcity?" Brookings Papers on Economic Activity, 2016(1): 1-69.

Smith, Matthew, Danny Yagan, Owen M. Zidar, and Eric Zwick. 2019. "Capitalists in the Twenty-first Century." The Quarterly Journal of Economics, 134(4): 1675-1745.

Tørsløv, Thomas R., Ludvig S. Wier, and Gabriel Zucman. 2020. "The Missing Profits of Nations." National Bureau of Economic Research. NBER Working Paper No. 24701. 
Figure 1: The Evolution of Pass-Through and Corporate Activity in the United States

A. Corporate-Sector Labor Share (1978-2017, BEA)

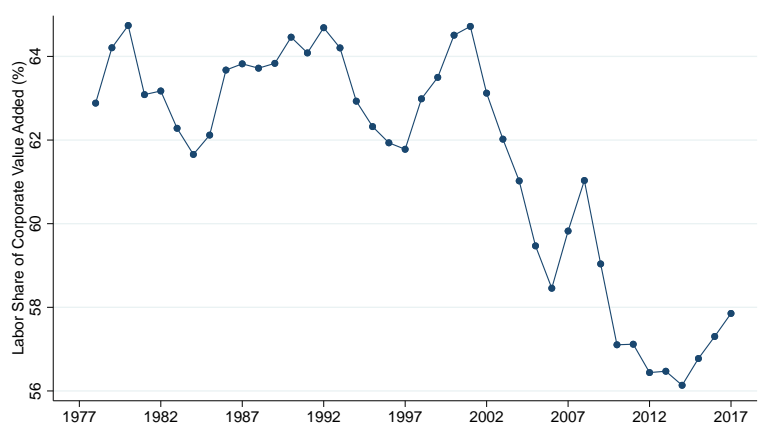

C. Business Activity in Pass-Through Form (1980-2016, SOI)

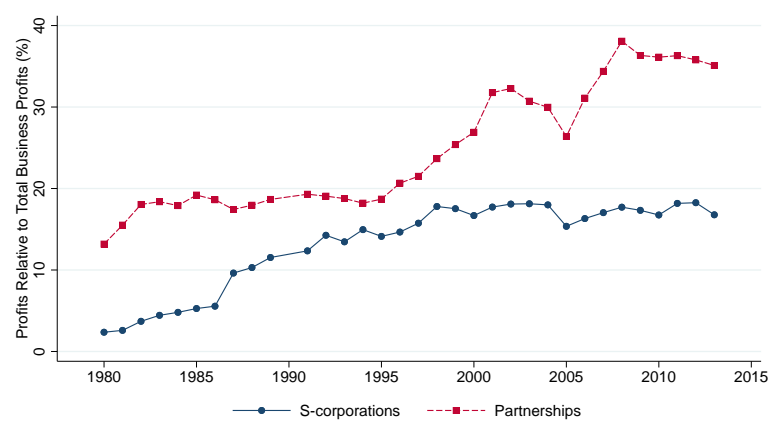

B. Corporate vs. Non-Corporate Gross Value Added (1978-2017, BEA)

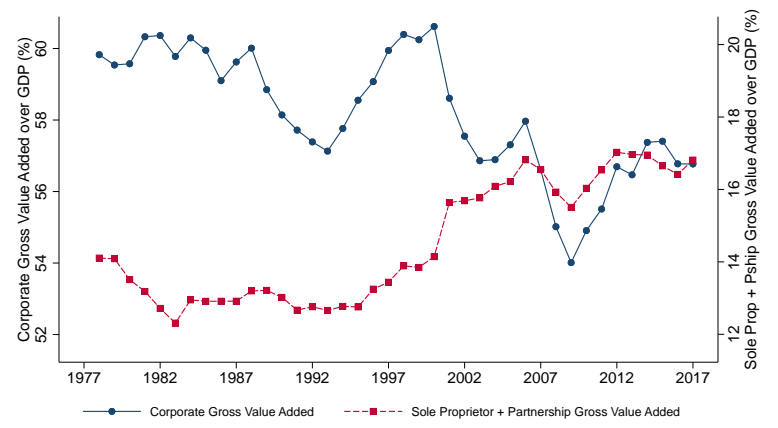

D. Value Added Across Selected Industry Groups by Organizatonal Form (SOI, 2017)

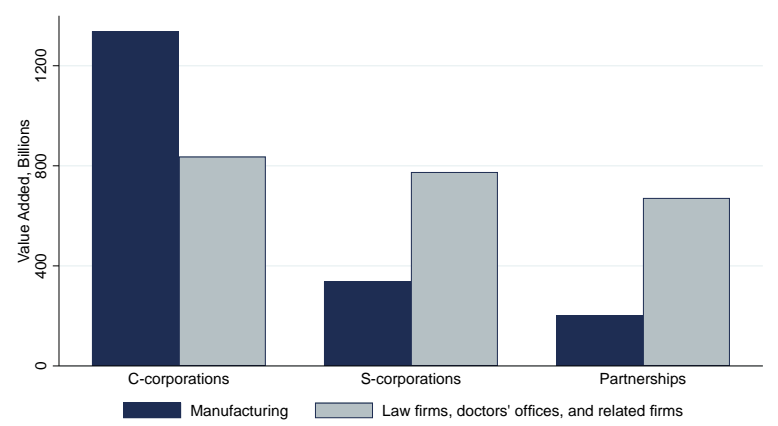

Notes: Panel A plots the labor share in the corporate sector defined as "Corporate Sector Compensation of Employees over Corporate Sector Gross Value Added" from the National Income and Product Accounts (NIPA) constructed by the Bureau of Economic Analysis. Panel B plots the share of business value added by organizational form. Aggregate corporate sector and sole proprietorship and partnership value added is sourced from NIPA Tables 1.14 and 7.5. Panel C shows profits of S-corporations and partnerships from IRS Statistics of Income (SOI) Income Tables. Panel D plots value added in key industry groups by organizational form, computed using SOI data. Manufacturing is NAICS 31-33, and law firms, doctors' offices, and related firms are NAICS 54 and 62 . 
Figure 2: Estimating Recharacterized Wages of Pass-through Business
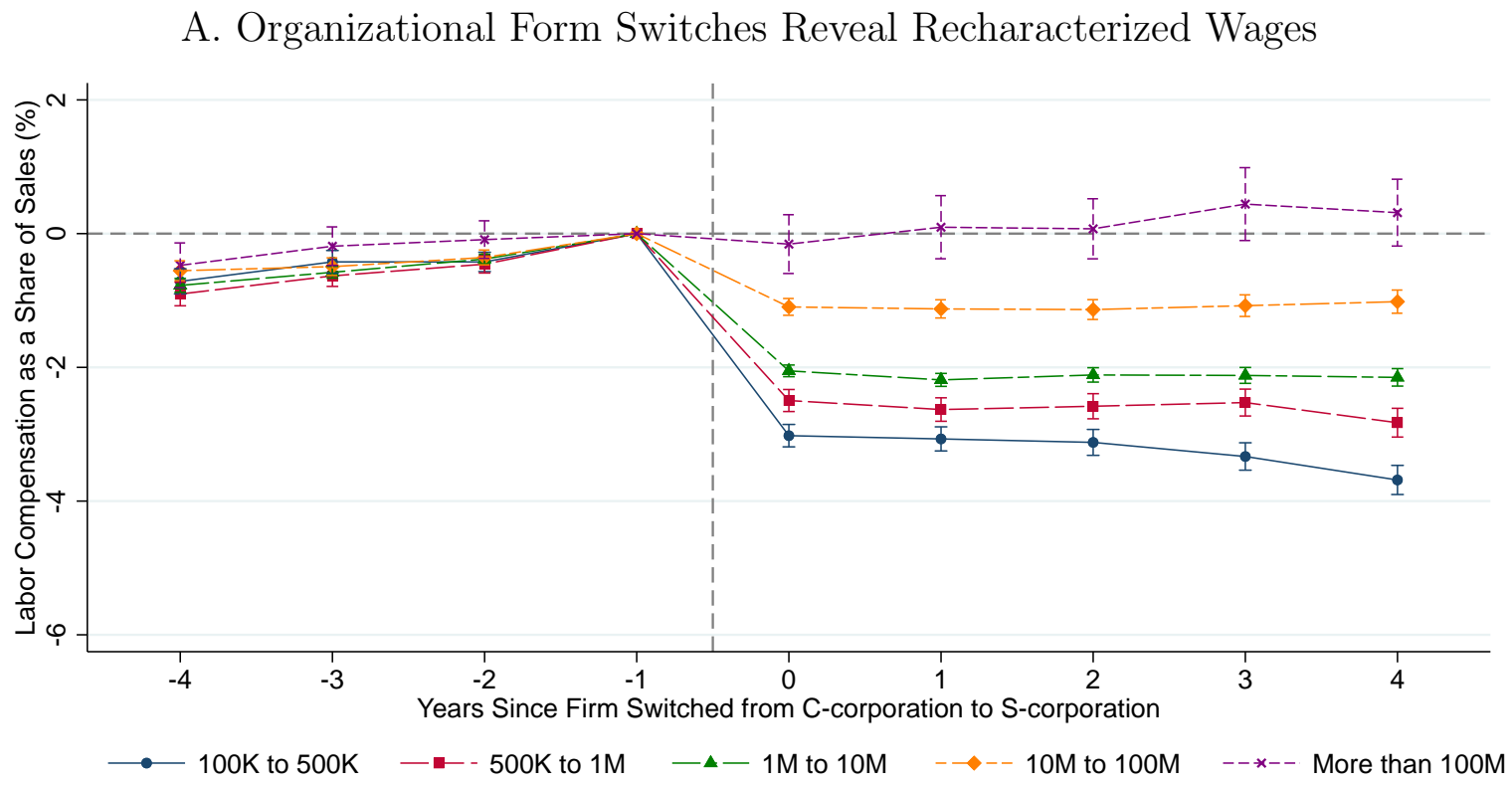

B. S-corporation Activity by Firm-Size Bin

C. Partnership Activity by Firm-Size Bin
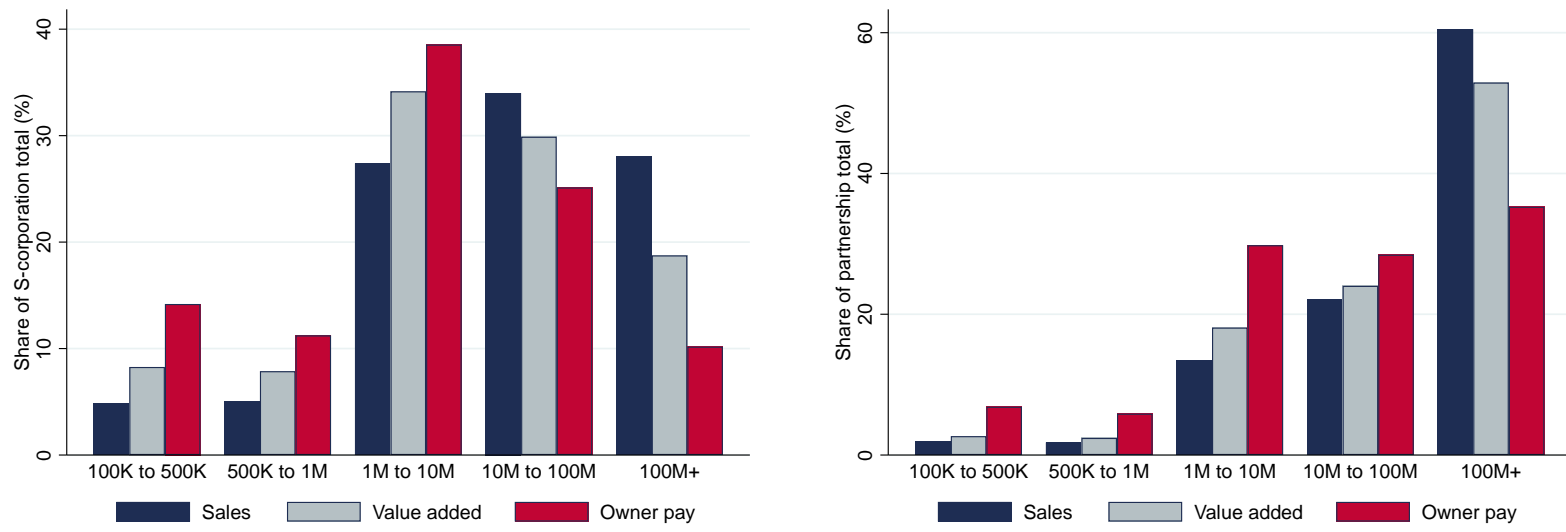

Notes: This figure shows inputs we use to compute recharacterized wages of S-corporations and partnerships. Panel A shows event-study estimates for equation (2), which describe the effect of organizational form switching on labor compensation as a share of sales, accounting for heterogeneity by business size (as measured by sales in constant 2014 dollars). Panels B and C show the distribution of sales and owner pay across the same size bins for S-corporations and partnerships, respectively. S-corporations with sales of less than $\$ 100 \mathrm{~K}$ account for $0.7 \%$ of aggregate owner pay and $0.64 \%$ of aggregate sales; partnerships with sales less than $\$ 100 \mathrm{~K}$ account for $-6.3 \%$ of aggregate owner pay and $0.34 \%$ of aggregate sales. Appendix Figure A. 8 shows how the relative size of these groups has evolved over time. We weight according to the sales distribution when averaging panel A's event-study estimates to yield an aggregate recharacterized wage share of S-corporation receipts. Bin-specific sales are from SOI samples and owner pay is from our linked firm-owner data. We show sales for 2017 and owner pay for the last available year, 2014. 
Figure 3: Adjusted Corporate-Sector Labor Shares (1978-2017)

\section{A. Adjusting for Recharacterized S-corporation Wages}

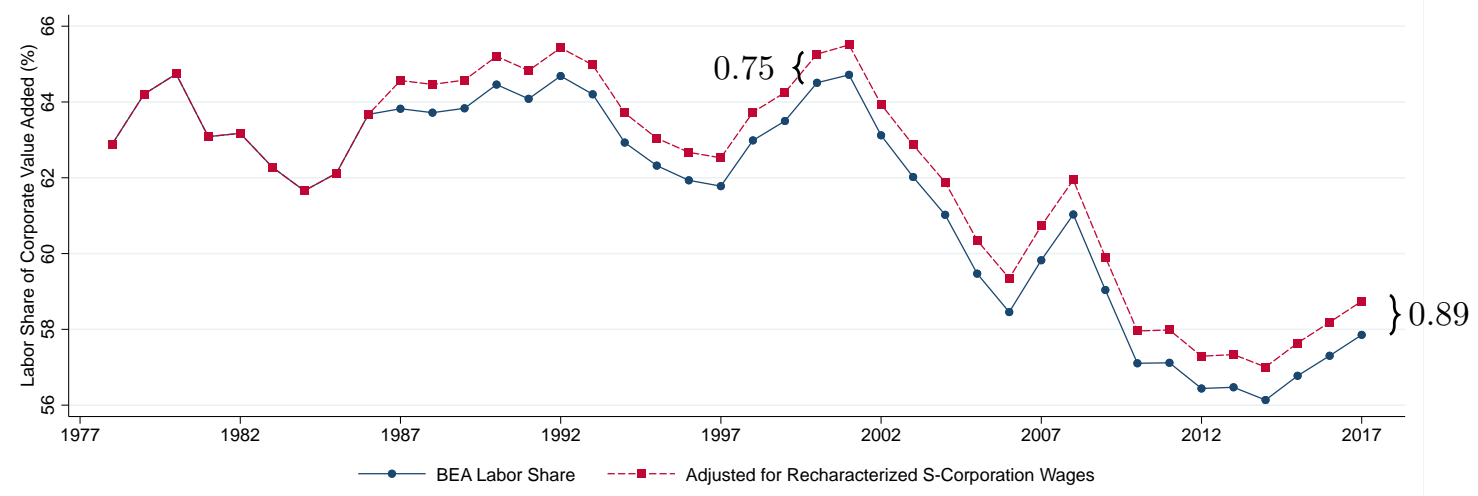

B. Adjusting for Partnership Growth in Noncorporate Sector

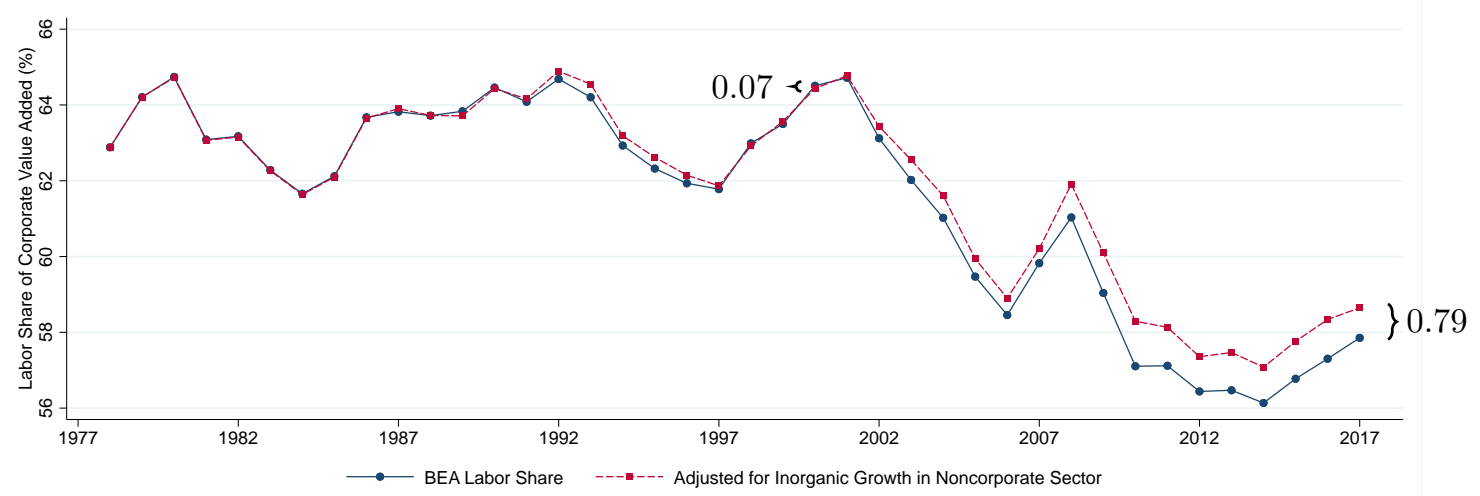

C. Combining Both Adjustments

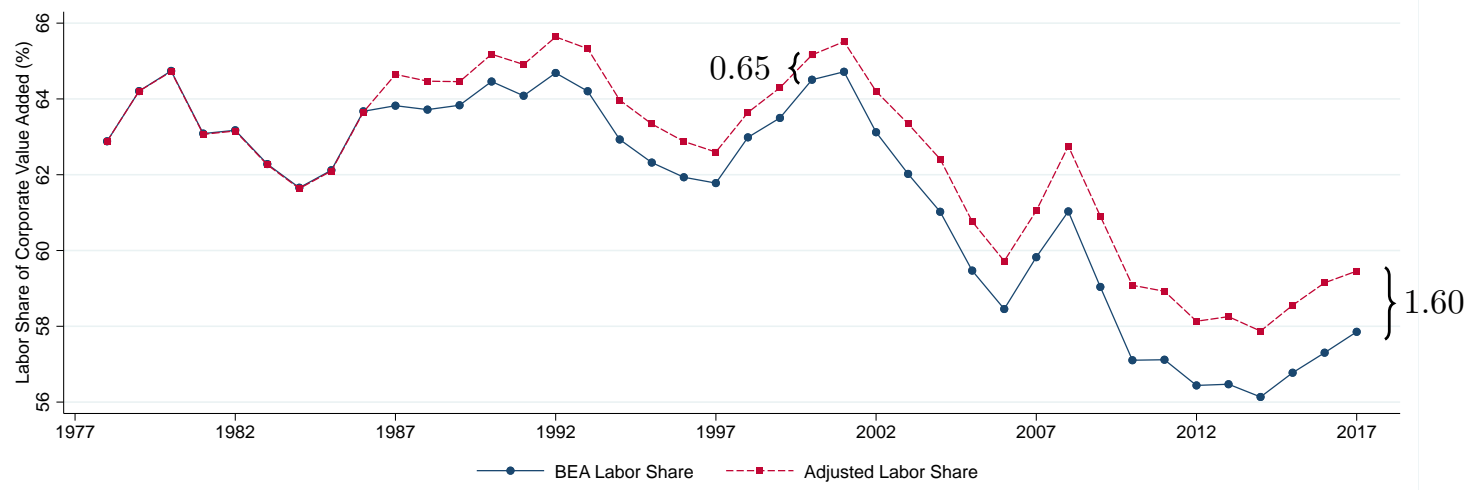

Notes: This figure plots adjusted corporate sectors against the headline labor share computed using NIPA table 1.14 aggregates (the "BEA labor share"). Panel A computes the labor share after adding our estimate of recharacterized wages of S-corporations to corporate-sector compensation. Specifically, we apply estimates from equation (2) for each firm-size bin and year. Panel B computes the labor share after adding excess partnership compensation growth and recharacterized wages of partnerships to corporate-sector compensation, and excess partnership gross value added growth to corporate-sector gross value added. We estimate recharacterized wages of partnerships by applying estimates from equation (3) for each firm-size bin and year. Panel C, our preferred series, combines these adjustments. 
Table 1: Calculation of Labor Share Adjustment (2017)

\begin{tabular}{lr}
\hline \hline \multicolumn{1}{c}{ Component } & 2017 \\
\hline A. BEA Corporate Labor Share & \\
\hline Corporate-sector employee compensation [BEA] & $\$ 6.42 \mathrm{~T}$ \\
Divided by: Corporate-sector gross value added [BEA] & $\$ 11.09 \mathrm{~T}$ \\
Equals: Corporate-sector labor share & $57.9 \%$ \\
& \\
B. Pass-through-adjusted Corporate Labor Share & $\$ 6.42 \mathrm{~T}$ \\
\hline Corporate-sector employee compensation [BEA] & $\$ 99 \mathrm{~B}$ \\
Plus: S-corporation recharacterized wages & $\$ 529 \mathrm{~B}$ \\
Plus: Excess partnership employee compensation & $\$ 187 \mathrm{~B}$ \\
Plus: Partnership recharacterized wages & \\
Divided by: & $\$ 11.09 \mathrm{~T}$ \\
Corporate-sector gross value added [BEA] & $\$ 529 \mathrm{~B}$ \\
Plus: Excess partnership employee compensation & $\$ 469 \mathrm{~B}$ \\
Plus: Excess partnership profits & $\$ 73 \mathrm{~B}$ \\
Plus: Excess partnership other capital income & $59.5 \%$
\end{tabular}

C. Adjustment components

S-corporation sales $[\mathrm{SOI}]$

$\$ 8.12 \mathrm{~T}$

Times: Recharacterized wages as a share of S-corporation sales $\quad 1.22 \%$

Equals: S-corporation recharacterized wages $\quad \$ 99 \mathrm{~B}$

Noncorporate employee compensation [BEA] $\quad \$ 1.13 \mathrm{~T}$

Times: Partnership share of noncorporate employee compensation [SOI] $\quad 82.2 \%$

Less: 1986 noncorporate employee compensation GDP-deflated to current year [BEA] \$396B

Equals: Excess partnership employee compensation $\$ 529 \mathrm{~B}$

Noncorporate profits (proprietors' income) [BEA] $\$ 1.50 \mathrm{~T}$

Times: Partnership share of profits [SOI/BEA] $\quad 72.3 \%$

Less: 1986 noncorporate proprietors' income GDP-deflated to current year [BEA] $\$ 619 \mathrm{~B}$

Equals: Excess partnership profits $\$ 469 \mathrm{~B}$

Noncorporate other capital income [BEA] $\$ 657 \mathrm{~B}$

Times: Partnership share of noncorporate other capital income [SOI] $\quad 81.5 \%$

Less: 1986 noncorporate other capital income GDP-deflated to current year [BEA] \$463B

Equals: Excess partnership other capital income $\$ 73 \mathrm{~B}$

Excess partnership profits [above] $+\mathrm{W}-2$ wages paid to partners [SOI] \$485B

Times: Wages as a share of profits $\quad 41.9 \%$

Less: W-2 wages paid to partners [SOI] $\quad \$ 17 \mathrm{~B}$

Equals: Partnership recharacterized wages $\quad \$ 187 \mathrm{~B}$

Notes: This table summarizes our adjustments to the corporate-sector labor share. Panel A uses aggregates from NIPA table 1.14 to compute the baseline labor share of corporate-sector gross value added. Panel B gives an overview of our adjustments, namely adding recharacterized wages of S-corporations and partnerships to labor compensation and adding excess partnership gross value added to corporate sector GVA. Panel C shows how we calculate each of the aggregates we use in Panel B to adjust the Panel A labor share. 
Table 2: Adjusting the Labor Share under Different Specifications

\begin{tabular}{|c|c|c|c|c|}
\hline & $\begin{array}{l}1978 \text { labor } \\
\text { share }(\%)\end{array}$ & $\begin{array}{l}2017 \text { labor } \\
\text { share }(\%)\end{array}$ & $\begin{array}{c}\text { Decline } \\
\text { 1978-2017 (pp) }\end{array}$ & $\begin{array}{c}\text { Share decline explained } \\
\text { by tax reporting (\%) }\end{array}$ \\
\hline \multicolumn{5}{|l|}{ A. Official estimate and main specification } \\
\hline Official BEA & 62.9 & 57.9 & 5.0 & \\
\hline Baseline adjustment & 62.9 & 59.5 & 3.4 & 31.9 \\
\hline \multicolumn{5}{|l|}{ B. Sensitivity analysis of recharacterized wage share } \\
\hline Use lower bound on switchers' confidence intervals & 62.9 & 59.6 & 3.3 & 34.4 \\
\hline Use upper bound on switchers' confidence intervals & 62.9 & 59.4 & 3.5 & 30.6 \\
\hline Use sales minus COGS denominator for switchers event study & 62.9 & 59.5 & 3.3 & 33.6 \\
\hline Treat large partnerships like mid-sized S-corporations & 62.9 & 59.9 & 3.0 & 40.4 \\
\hline \multicolumn{5}{|l|}{ C. Sensitivity analysis of GDP inflation correction } \\
\hline Keep corporate share of total VA constant at 1986 levels & 62.9 & 59.2 & 3.7 & 26.8 \\
\hline \multicolumn{5}{|l|}{ D. Joint sensitivity analysis with GDP inflation correction alternative } \\
\hline Use confidence interval lower bounds + Keep corp. share constant & 62.9 & 59.3 & 3.6 & 29.4 \\
\hline Use confidence interval upper bounds + Keep corp. share constant & 62.9 & 59.1 & 3.7 & 25.5 \\
\hline Treat large Pships like mid-sized S + Keep corp. share constant & 62.9 & 59.5 & 3.4 & 32.7 \\
\hline
\end{tabular}

Table 1. 


\section{For Online Publication}

\section{A Appendix}

This appendix contains supplemental analysis. 


\section{Figure A.1: Organizational Form Switches Reveal Recharacterized Wages}

A. All Switchers

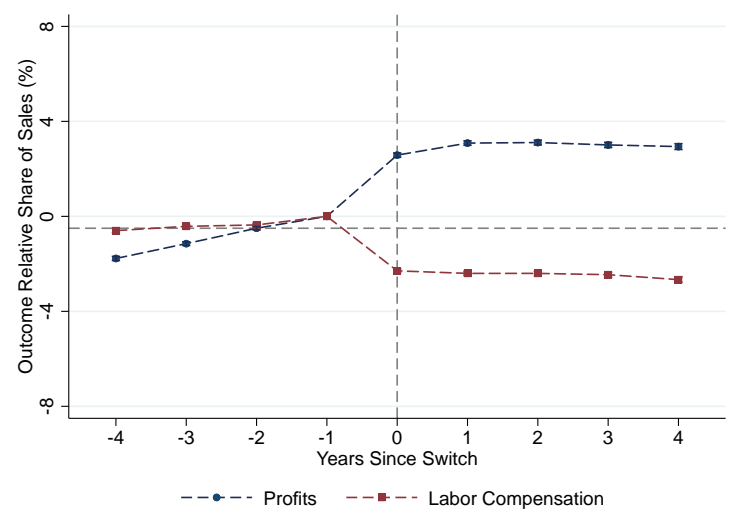

B. Industry Heterogeneity

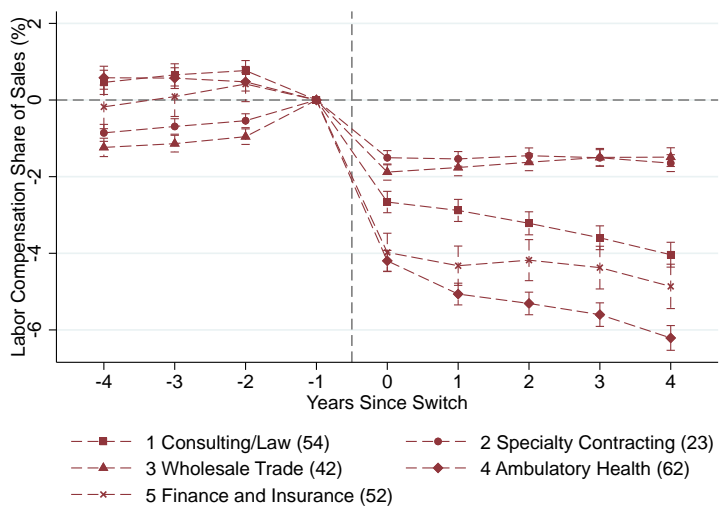

Notes: This figure presents event-study analyses examining how labor payments and profits change after a firm reorganizes from C-corporation form to S-corporation form. We run regressions as in (1) and plot the event-time coefficients, where the outcome variable is either total wage payments or profits over firm sales, and estimates include firm and calendar-year fixed effects. The sample includes switcher firms from between 2000 and 2012 with maximum sales greater than $\$ 100 \mathrm{~K}$ in 2014 dollars, which exist for at least four years before and after the switch event. Panel A plots the coefficients for firm-level profits and labor compensation for the full analysis sample. Panel B plots separate labor compensation coefficients for firms in the five largest (two-digit NAICS) industries in terms of S-corporation profits in 2017.

Figure A.2: Switcher Characteristics During Organizational Form Switches

A. $\log ($ Number of Workers)

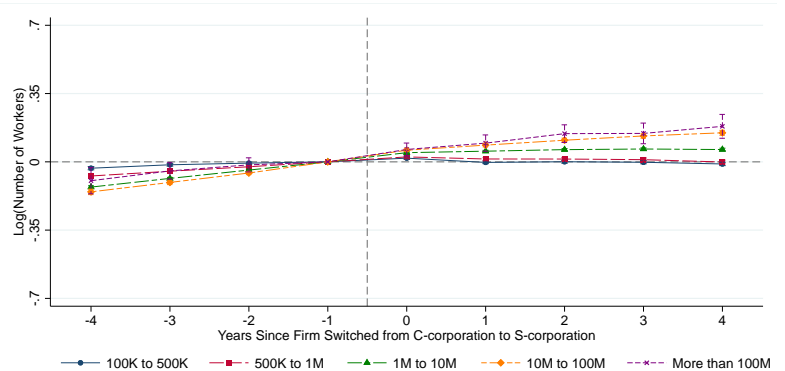

B. $\log ($ Sales $)$

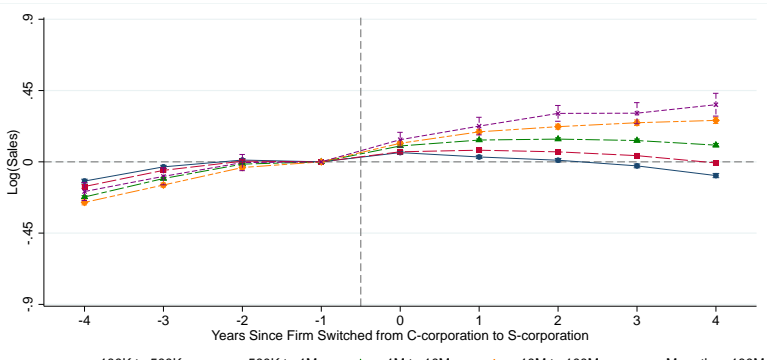

Notes: This figure plots event studies that examine other firm characteristics around switches from Ccorporation to S-corporation form. Observations are trimmed at the one percent level. To ensure comparability of outcomes across time periods, we exclude firms that file partial year returns during $t=0$ because they had to change their fiscal years following the switch. Panel A plots the natural logarithm of the number of workers, and Panel B plots the natural logarithm of sales in 2014 U.S. dollars. The y-axes are scaled to range from plus or minus 0.5 standard deviations of the respective outcome variable. 
Figure A.3: Adjusted Corporate Sector Value Added

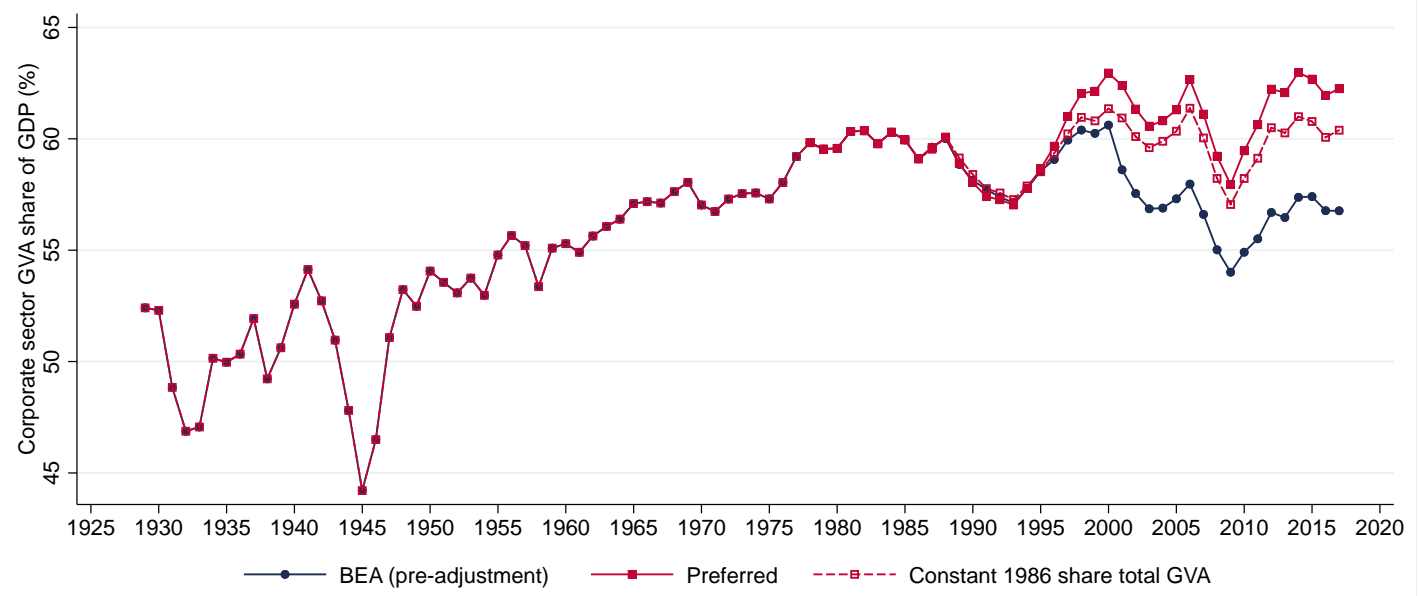

Notes: This figure plots gross value added (GVA) in the corporate sector relative to GDP. The BEA series takes total corporate sector GVA directly from line 1 of NIPA Table 1.14. The Preferred series adds gross value added from the partnership sector which, under our counterfactual adjustments shown in Figure 3, would have remained in the corporate sector. The "Constant 1986 share total GVA" series, which relates to Table $2 \mathrm{C}$, shows corporate sector GVA as it would have been if it had remained the same share of corporate, sole proprietorship, and partnership GVA as in 1986. 
Figure A.4: Adjusted Overall Labor Shares (1978-2017)

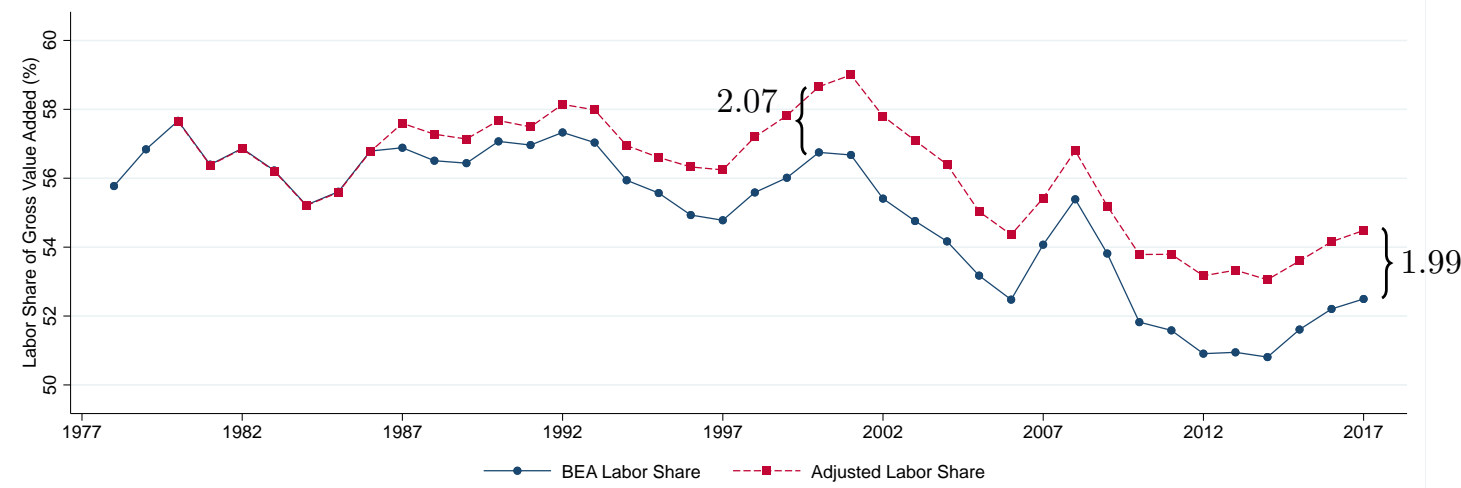

Notes: This figure plots the effect of applying our S-corporation and partnership adjustments to the overall labor share. This adjustment adds S-corporation recharacterized wages and the wage share of excess partnership profits to the numerator of the overall labor share and includes the entire noncorporate business sector in the denominator. Since both corporate and noncorporate activity are both represented in the denominator, we make no changes to the raw BEA gross value added series. Over the 1978-2017 period, our overall labor share series after both adjustments shows a decline of 1.3 percentage points, $60.8 \%$ (2.0pp) smaller than the 3.3 percentage point decline in the raw BEA data. Relative to Figure 3C, our adjustments increase the overall labor share more in earlier years because of the relationship between the unadjusted labor share and the post-adjustment partnership labor share. Specifically, partnerships in the early 2000s have a similar labor share to the corporate sector, so adding them does not move the corporate sector share. However, they have a higher labor share than the overall series due to lower labor shares in the noncorporate sector. Accordingly, adding recharacterized partnership wages increases the noncorporate labor share and thereby the overall labor share substantially.

Figure A.5: The Evolution of Organizational Form Choice for Lawyers

\section{A. Number of Law Firms}

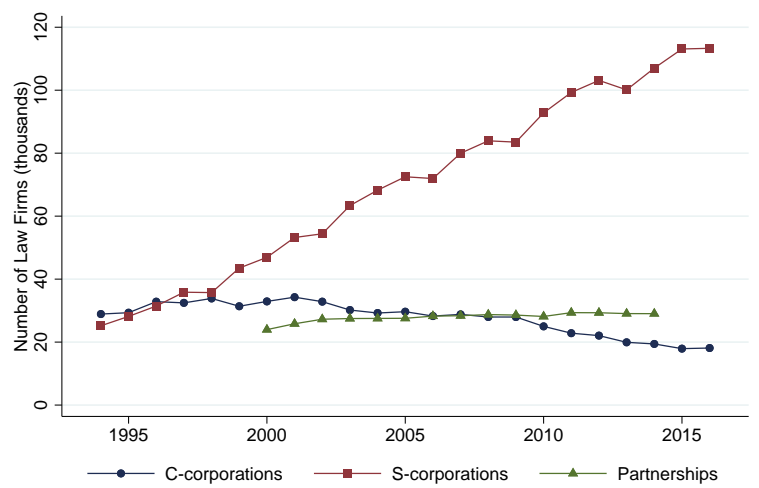

B. Share of Activity

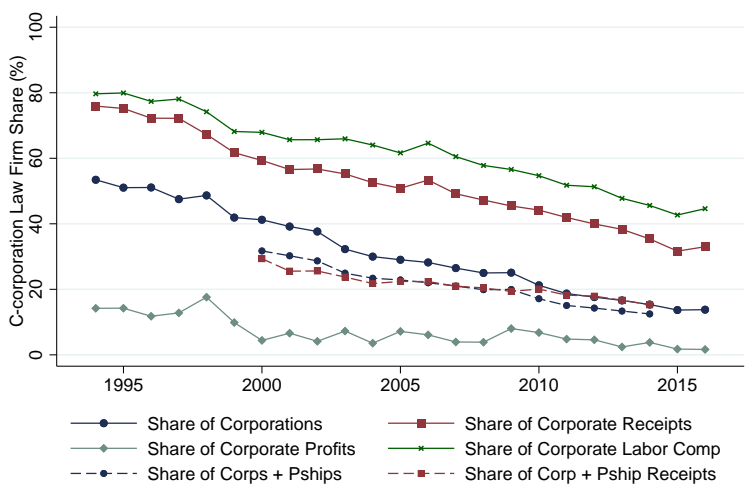

Notes: For tax years from 1998 onward, we use NAICS code 5411. For tax years prior to 1998, we use SOI Principal Business Activity code 8111. 
Figure A.6: The Manufacturing Sector Drives the Labor Share Decline (1987-2017)

\section{A. Shift-Share Decomposition}

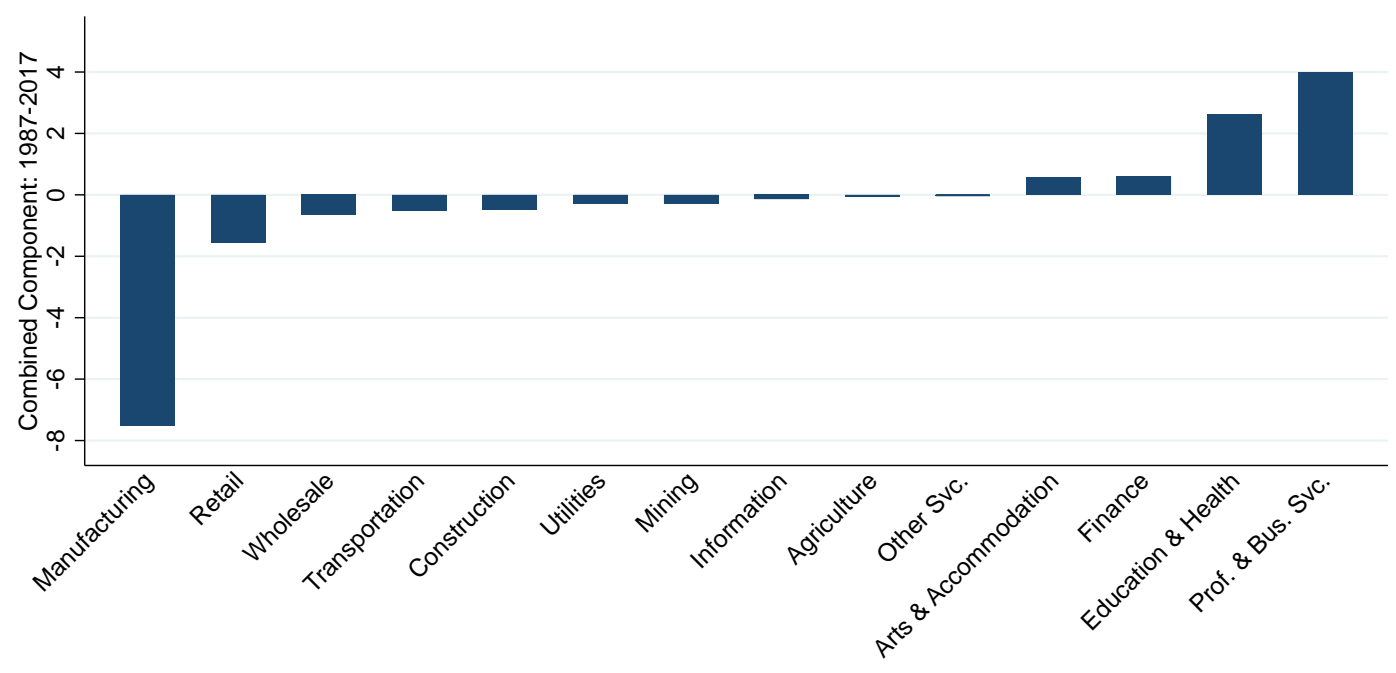

B. Cumulative Labor Share Decline with and without Manufacturing

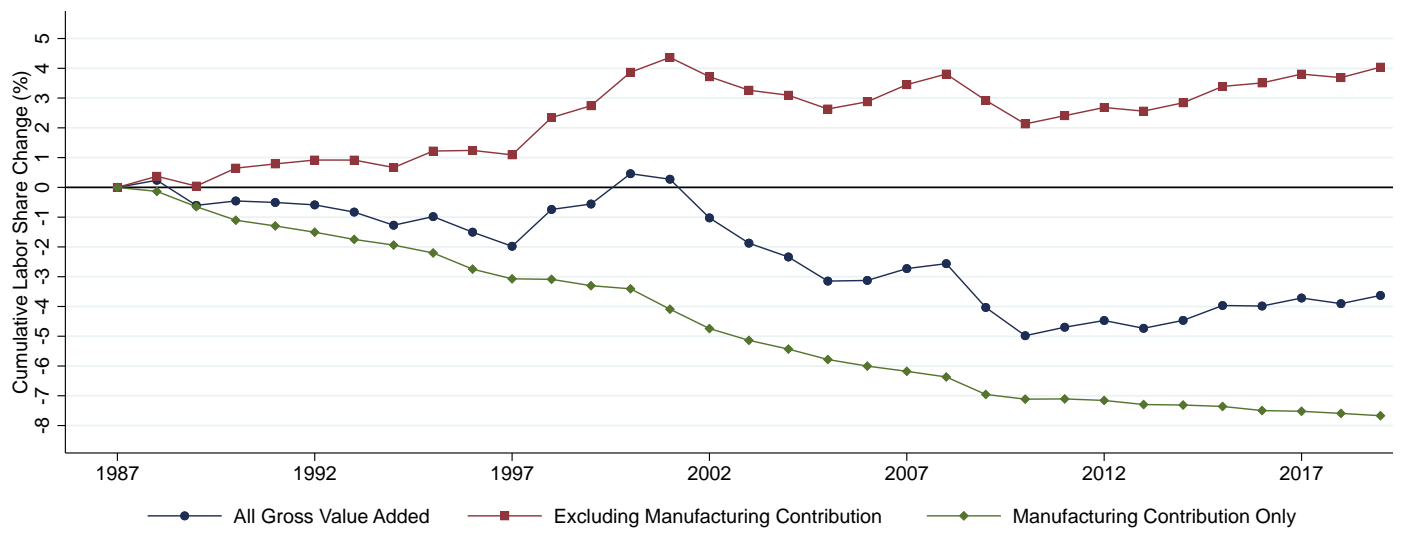

Notes: This figure presents evidence highlighting the role of the manufacturing sector in the decline of the labor share. Data come from the BEA industry accounts, as in Elsby, Hobijn and Şahin (2013). Panel A presents the contribution of different industries to the decline in the labor share from 1987 to 2017. The bars in blue show the contributions in the raw data and the red bars show the contributions after adjusting both for the recharacterized wages of S-corporations and for businesses organized as partnerships. Panel B presents the cumulative change in the labor share from 1987 to 2017, excluding our adjustments for the passthrough sector. The blue line shows the cumulative decline in the labor share of all gross value added, the red line shows the cumulative change in the labor share after excluding any change due to the manufacturing sector, and the green line shows the cumulative contribution from the manufacturing sector. 
Figure A.7: Corporate-Sector Labor Share Decline in the OECD

A. Balanced Sample (1987-2011)

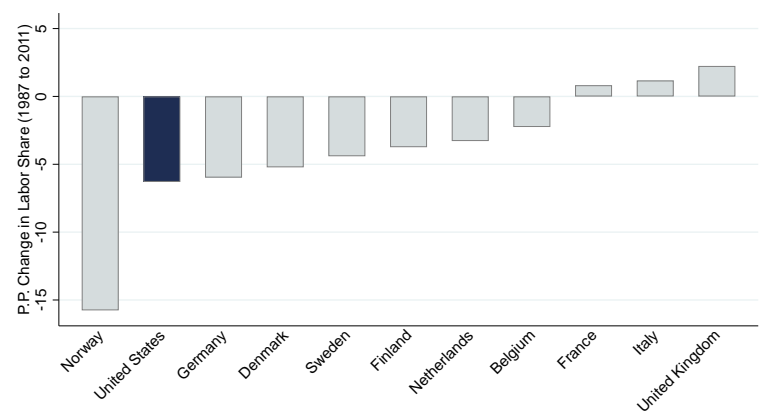

C. Combining Small Countries (1995-2011)

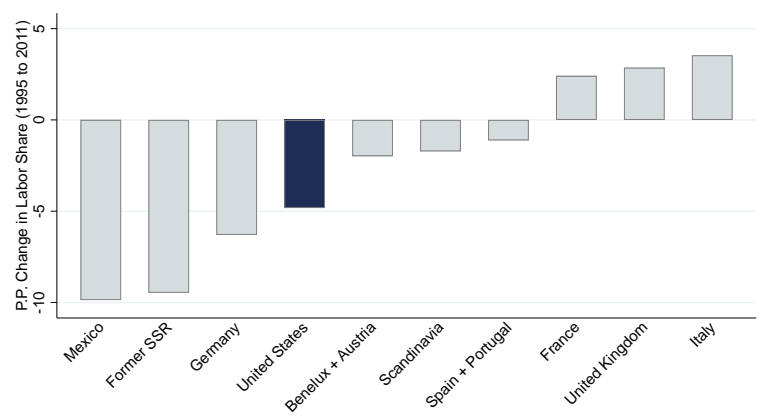

B. Balanced Sample (1995-2011)

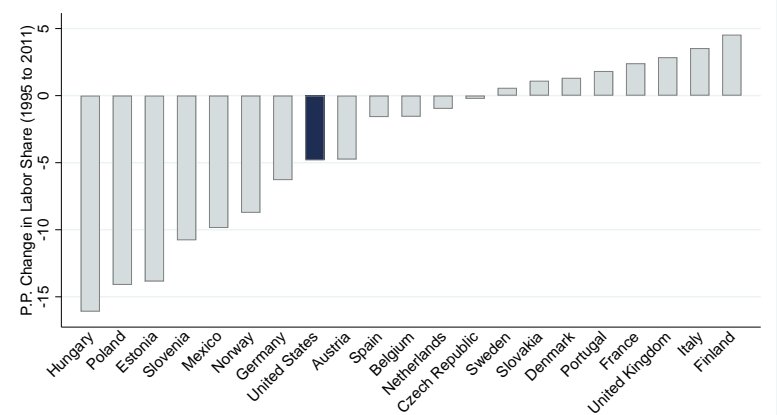

D. Combining Small Countries (1995-2017)

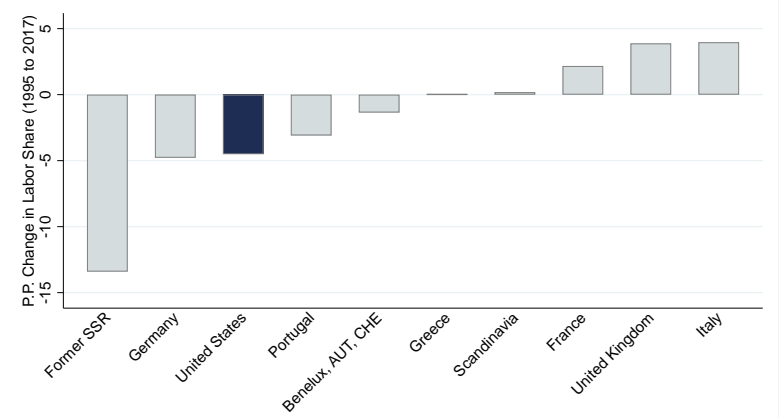

Notes: This figure shows the decline in the corporate-sector labor share in OECD countries. In panels A-C, we use the exact series from Karabarbounis and Neiman (2014), which end in 2011, to aid comparison to their results. Panel D uses data from the UN National Accounts Official Country Data database. Each graph plots the percentage point change between a beginning year and an end year. Panel A includes the OECD countries for which data are available from 1987 through 2011. Panel B plots the change from 1995 to 2011 for a broader set of OECD countries with available data. Panels C and D aggregate smaller countries by region and compute a weighted average labor share change, where the weights are corporate-sector gross value added in 2011 and 2017, respectively. 


\section{Figure A.8: Pass-through Value Added by Firm-Size Bin}

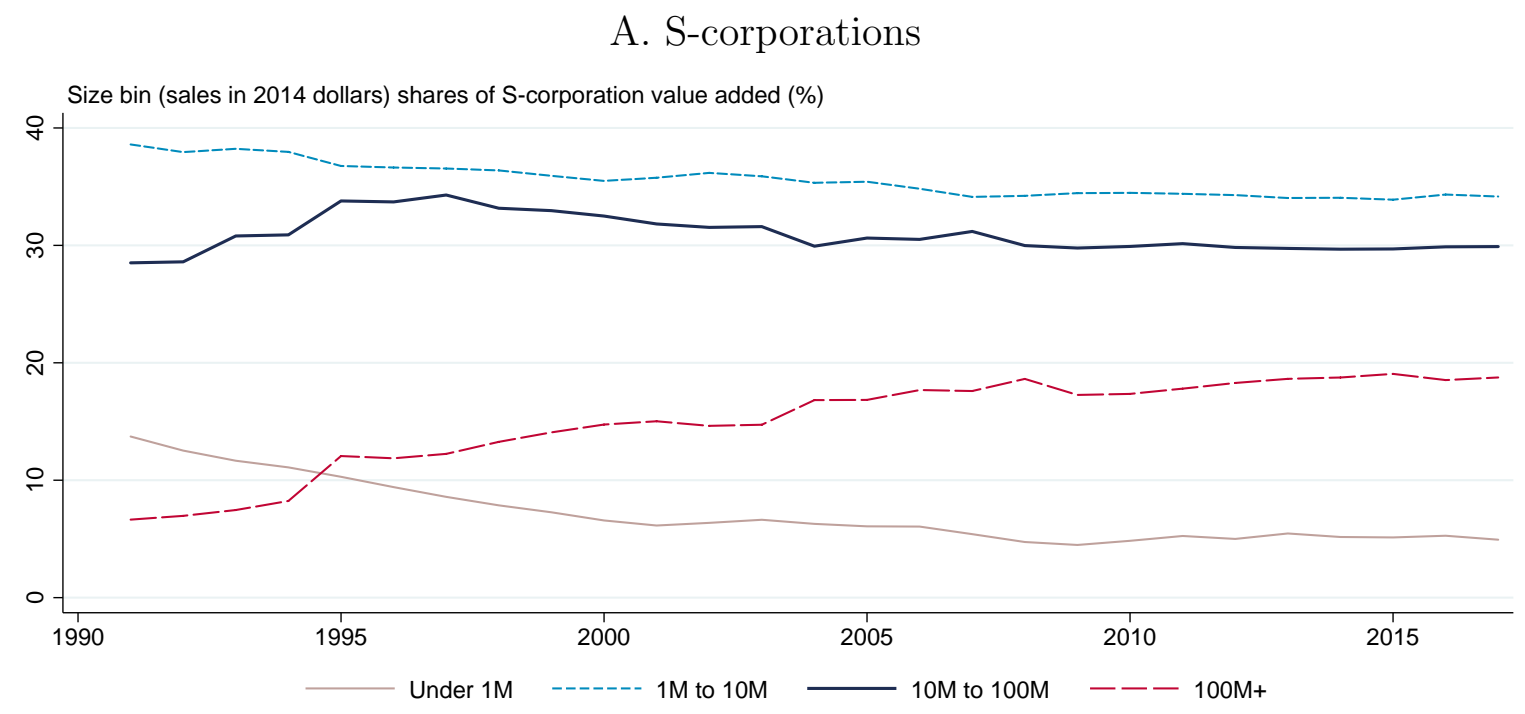

\section{B. Partnerships}

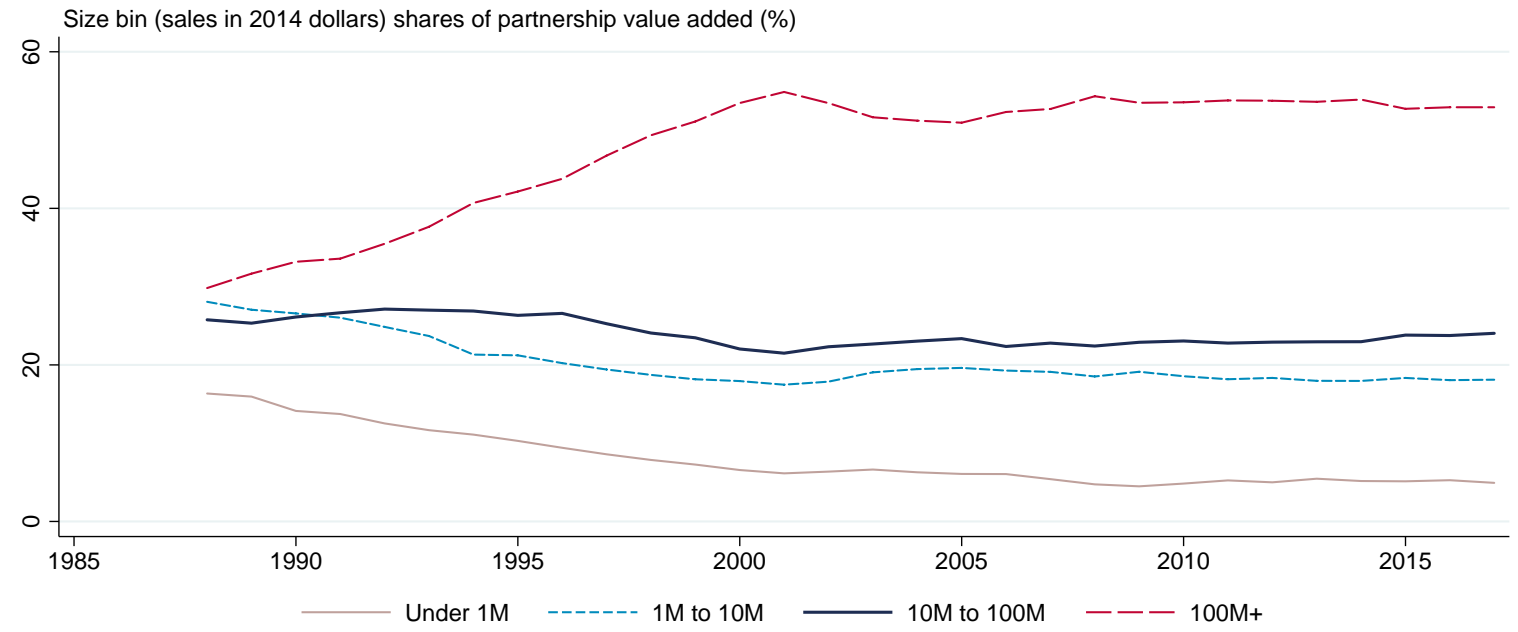

Notes: This figure extends the value added series from panels B and C of Figure 2 to show shares from 1987 (partnerships) or 1991 (S-corporations) to 2017. Bottom bins are condensed into a single "under 1M" bin. 
Table A.1: Industry Composition of Labor-Share Adjustments (2017, \$B)

\begin{tabular}{|c|c|c|c|c|c|c|c|}
\hline & \multirow[b]{2}{*}{ NAICS } & \multirow[b]{2}{*}{ Industry Name } & \multicolumn{3}{|c|}{ Adjustments } & \multicolumn{2}{|c|}{2017 Baseline (BEA) } \\
\hline & & & Combined & S-corporation & Partnership & Value added & Share total (\%) \\
\hline 1 & 541 & Professional, Sctfc., \& Technical Svc. & 51.8 & 19.3 & 32.4 & 1456.7 & 8.5 \\
\hline 2 & 621 & Ambulatory Health Care Svc. & 27.1 & 18.6 & 8.5 & 711.7 & 4.2 \\
\hline 3 & 523 & Securit., Cmmdty Cntrcts, \& Oth. Fin. & 21.1 & 3.2 & 17.9 & 304.3 & 1.8 \\
\hline 4 & 238 & Specialty Trade Contractors & 6.6 & 5.1 & 1.5 & $797.8^{\dagger}$ & $4.7^{\dagger}$ \\
\hline 5 & 211 & Oil \& Gas Extraction & 6.4 & 0.3 & 6.1 & 174.6 & 1.0 \\
\hline 6 & 423 & Merchant Wholesalers, Durable Gds. & 5.4 & 3.9 & 1.5 & $1163.5^{\dagger}$ & $6.8^{\dagger}$ \\
\hline 7 & 561 & Administrative \& Support Svc. & 4.7 & 3.5 & 1.2 & 548.2 & 3.2 \\
\hline 8 & 531 & Real Estate & 4.6 & 3.8 & 0.8 & 2377.4 & 13.9 \\
\hline 9 & 424 & Merchant Wholesalers, Nondurable Gds. & 4.4 & 2.6 & 1.8 & $1163.5^{\dagger}$ & $6.8^{\dagger}$ \\
\hline 10 & 517 & Telecommunications & 3.8 & 0.3 & 3.5 & $1005.4^{\dagger}$ & $5.9^{\dagger}$ \\
\hline 11 & 524 & Insurance Carriers & 3.7 & 2.8 & 1.0 & 560.6 & 3.3 \\
\hline 12 & 623 & Nursing \& Residential Care Facilities & 2.9 & 2.9 & 0.0 & 145.8 & 0.9 \\
\hline 13 & 111 & Crop Production & 2.8 & 0.7 & 2.1 & 140.1 & 0.8 \\
\hline 14 & 522 & Credit Intermediation & 2.8 & 1.5 & 1.2 & 625.9 & 3.7 \\
\hline 15 & 236 & Construction of Buildings & 2.8 & 1.9 & 0.8 & $797.8^{\dagger}$ & $4.7^{\dagger}$ \\
\hline 16 & 722 & Food Svc. \& Drinking Places & 2.1 & 1.3 & 0.8 & 440.9 & 2.6 \\
\hline 17 & 325 & Chemical Mfg. & 2.1 & 0.4 & 1.7 & 358.3 & 2.1 \\
\hline 18 & 332 & Fabricated Metal Product Mfg. & 2.0 & 1.6 & 0.5 & 149.2 & 0.9 \\
\hline 19 & 441 & Motor Vehicle \& Parts Dealers & 1.9 & 1.0 & 0.9 & 207.3 & 1.2 \\
\hline \multirow[t]{2}{*}{20} & 711 & Performing Arts, Spectator Sports, \& Related Industries & 1.8 & 1.8 & 0.0 & 129.2 & 0.8 \\
\hline & & Total & 195.1 & 98.7 & 96.4 & 17094.2 & 100 \\
\hline
\end{tabular}

Notes: Table A.1 disaggregates the labor-share adjustments, showing the adjustments by three-digit NAICS industry for the twenty industries with the largest combined labor-share adjustment. The "Combined" column presents the total labor-share adjustment. The "S-corporation" column shows the contribution from S-corporation recharacterized wages, based on event-study estimates with sector heterogeneity (partially shown in figure A.1) and apportioned into 3-digit industries using industry value added shares from SOI corporate sample collapses. The "Partnership" column shows the contribution from reincorporating firms organized as partnerships with labor shares in excess of the corporate-sector labor share, apportioned using industry profits shares from firm-owner linked data collapses. In terms of Table 1 items, it represents the sum of "excess partnership compensation" and "recharacterized wages of partnerships" minus the labor share of total "excess gross value added." For both S-corporations and partnerships, we apportion the 2017 adjustment using 2014 value added and profits shares, respectively, as 2014 is the last year in which we have firm-owner linked partnership data. The "2017 Baseline" columns, which we show for reference but are not inputs for our adjustment, are from the BEA GDP-by-industry accounts. Gross value added in these columns encompasses both corporate and non-corporate business. Totals and shares marked with $\dagger$ are two-digit totals, which we show for three-digit industries not disaggregated by the BEA. Note that NAICS 531 comprises two industries with very low human capital shares - lessors of real estate (5311) and activities related to real estate, e.g., property managers (5313) - and one industry with a very high human capital share - offices of real estate agents and brokers (5312). This latter industry accounts for the bulk of our adjustment. 
Table A.2: Switcher and Stayer Summary Statistics

\begin{tabular}{lrrrrrrr}
\hline Attribute & Mean & Standard deviation & P5 & P25 & P50 & P75 & P95 \\
\hline A. Switchers & & & & & & & \\
Labor compensation & 521,071 & 921,182 & 0 & 39,753 & 187,437 & 564,042 & $2,271,228$ \\
Profits & 76,388 & 235,859 & $-46,920$ & 0 & 11,363 & 61,716 & 406,636 \\
Labor Share & 0.39 & 0.22 & 0.00 & 0.24 & 0.41 & 0.55 & 0.73 \\
Sales less COGS & $1,157,034$ & $1,949,744$ & 0 & 156,970 & 481,322 & $1,250,088$ & $4,751,944$ \\
Effective Tax & 0.16 & 0.11 & 0.00 & 0.15 & 0.15 & 0.22 & 0.35 \\
& & & & & & & \\
B. Stayers & & & & & & & \\
Labor compensation & 486,748 & $1,118,675$ & 9,342 & 49,514 & 148,740 & 422,362 & $2,018,029$ \\
Profits & 23,145 & 229,729 & $-127,910$ & $-9,312$ & 1,644 & 27,485 & 205,639 \\
Labor Share & 0.45 & 0.22 & 0.09 & 0.29 & 0.45 & 0.60 & 0.81 \\
Sales less COGS & 994,430 & $2,261,072$ & 30,054 & 137,484 & 347,939 & 872,948 & $3,870,114$ \\
Effective Tax & 0.09 & 0.11 & 0.00 & 0.00 & 0.00 & 0.15 & 0.34 \\
& & & & & & & \\
\hline
\end{tabular}

Notes: This table shows summary statistics describing firms in our "switchers" sample of firms, drawn from the population of S- and C-corporation tax returns, as well as a "stayers" sample. Switchers are defined as firms that switch from C- to S- corporation form during our sample period. Switcher summary statistics are given for the two years preceding a switching event. Stayers are defined as firms that are C-corporations in 2006 and did not experience a C- to S-corporation switching event in our sample period. Observations for Labor Compensation, Profits, and Sales less Cost of Goods Sold (COGS) are trimmed at the one percent level. Labor Compensation, Profits, and Sales less COGS are in 2014 U.S. dollars. Labor Compensation includes wage payments and benefits. Labor Share is the ratio of Labor Compensation to Sales less COGS. Effective Tax Rate is defined as the ratio of total tax to taxable income from the firm's tax return. Number of switcher observations: $188 \mathrm{~K}$. Number of stayer observations: $1.03 \mathrm{M}$. 
Table A.3: Switchers and Stayers by Industry

\begin{tabular}{lllll}
\hline Rank & Industry & Naics Code & Switcher Share & Stayer Share \\
\hline 1 & Professional, Scientific, and Technical Services & 541 & 12.4 & 12.3 \\
2 & Ambulatory Health Care Services & 621 & 9.7 & 8.2 \\
3 & Specialty Trade Contractors & 238 & 8.3 & 8.5 \\
4 & Real Estate & 531 & 5.3 & 3.7 \\
5 & Merchant Wholesalers, Durable Goods & 423 & 4.5 & 5 \\
6 & Food Services and Drinking Places & 722 & 3.7 & 4.9 \\
7 & Construction of Buildings & 236 & 3.6 & 3.3 \\
8 & Merchant Wholesalers, Nondurable Goods & 424 & 3 & 3 \\
9 & Personal and Laundry Services & 812 & 2.9 & 3.2 \\
10 & Repair and Maintenance & 811 & 2.8 & 3.3 \\
11 & Administrative and Support Services & 561 & 2.6 & 2.9 \\
12 & Insurance Carriers and Related Activities & 524 & 2.4 & 1.8 \\
13 & Motor Vehicle and Parts Dealers & 441 & 2.3 & 2.2 \\
14 & Food and Beverage Stores & 445 & 2.1 & 2.4 \\
15 & Miscellaneous Store Retailers & 453 & 1.9 & 2.4 \\
16 & Fabricated Metal Product Manufacturing & 332 & 1.8 & 1.6 \\
17 & Unclassified Industry & 999 & 1.5 & 1.4 \\
18 & Truck Transportation & 484 & 1.4 & 1 \\
19 & Crop Production & 111 & 1.1 & 1.1 \\
20 & Miscellaneous Manufacturing & 339 & 1 & 25.9 \\
21 & Other & Residual & 25.6 & \\
\hline
\end{tabular}

Notes: This table shows the composition of our sample of switchers and stayers by NAICS industry. Switchers are defined as firms that switch from C- to S- corporation form during our sample period. Stayers are defined as firms that are C-corporations in 2006 and did not experience a C- to S-corporation switching event in our sample period. 
Table A.4: Event-study results across specifications

\begin{tabular}{|c|c|c|c|c|c|c|}
\hline & $\begin{array}{l}\text { Pooled } \\
\text { (1) }\end{array}$ & $\begin{array}{c}\text { Omit t-2 } \\
(2)\end{array}$ & $\begin{array}{l}\text { Early } \\
(3)\end{array}$ & $\begin{array}{l}\text { Late } \\
(4)\end{array}$ & \multicolumn{2}{|c|}{$\begin{array}{c}\text { Services } \\
\quad(5)\end{array}$} \\
\hline$t=0$ & $\begin{array}{l}-2.29 \\
(0.04)\end{array}$ & $\begin{array}{l}-1.93 \\
(0.04)\end{array}$ & $\begin{array}{l}-2.52 \\
(0.05)\end{array}$ & $\begin{array}{l}-1.97 \\
(0.07)\end{array}$ & \multicolumn{2}{|c|}{$\begin{array}{l}-2.68 \\
(0.32)\end{array}$} \\
\hline$t=1$ & $\begin{array}{l}-2.40 \\
(0.04)\end{array}$ & $\begin{array}{l}-2.04 \\
(0.05)\end{array}$ & $\begin{array}{l}-2.70 \\
(0.06)\end{array}$ & $\begin{array}{l}-2.03 \\
(0.09)\end{array}$ & \multicolumn{2}{|c|}{$\begin{array}{l}-2.73 \\
(0.32)\end{array}$} \\
\hline$t=2$ & $\begin{array}{l}-2.40 \\
(0.05)\end{array}$ & $\begin{array}{l}-2.04 \\
(0.05)\end{array}$ & $\begin{array}{l}-2.73 \\
(0.07)\end{array}$ & $\begin{array}{l}-2.07 \\
(0.12)\end{array}$ & \multicolumn{2}{|c|}{$\begin{array}{l}-2.75 \\
(0.33)\end{array}$} \\
\hline$t=3$ & $\begin{array}{l}-2.45 \\
(0.05)\end{array}$ & $\begin{array}{l}-2.09 \\
(0.06)\end{array}$ & $\begin{array}{l}-2.84 \\
(0.09)\end{array}$ & $\begin{array}{l}-2.16 \\
(0.14)\end{array}$ & \multicolumn{2}{|c|}{$\begin{array}{l}-2.86 \\
(0.34)\end{array}$} \\
\hline$t=4$ & $\begin{array}{l}-2.66 \\
(0.06)\end{array}$ & $\begin{array}{l}-2.30 \\
(0.06)\end{array}$ & $\begin{array}{l}-3.08 \\
(0.10)\end{array}$ & $\begin{array}{l}-2.44 \\
(0.17)\end{array}$ & \multicolumn{2}{|c|}{$\begin{array}{l}-3.30 \\
(0.35)\end{array}$} \\
\hline Mean impact & -2.44 & -2.08 & -2.78 & -2.13 & \multicolumn{2}{|c|}{-2.86} \\
\hline Observations & $\begin{array}{c}183,297 \\
2082\end{array}$ & $\begin{array}{c}183,297 \\
2082\end{array}$ & 111,301 & $\begin{array}{c}71,996 \\
1,132,156\end{array}$ & \multicolumn{2}{|c|}{$\begin{array}{c}60,089 \\
2760333\end{array}$} \\
\hline & & $\begin{array}{c}100-500 \mathrm{~K} \\
(7)\end{array}$ & $\begin{array}{c}500 \mathrm{~K}-1 \mathrm{M} \\
(8)\end{array}$ & $\begin{array}{c}1-10 \mathrm{M} \\
(9)\end{array}$ & $\begin{array}{c}10-100 \mathrm{M} \\
(10)\end{array}$ & $\begin{array}{c}>100 \mathrm{M} \\
(11)\end{array}$ \\
\hline$t=0$ & & $\begin{array}{l}-3.02 \\
(0.09)\end{array}$ & $\begin{array}{l}-2.50 \\
(0.08)\end{array}$ & $\begin{array}{l}-2.05 \\
(0.04)\end{array}$ & $\begin{array}{l}-1.10 \\
(0.06)\end{array}$ & $\begin{array}{l}-0.16 \\
(0.22)\end{array}$ \\
\hline$t=1$ & & $\begin{array}{l}-3.07 \\
(0.09)\end{array}$ & $\begin{array}{l}-2.63 \\
(0.09)\end{array}$ & $\begin{array}{l}-2.19 \\
(0.05)\end{array}$ & $\begin{array}{l}-1.13 \\
(0.07)\end{array}$ & $\begin{array}{c}0.10 \\
(0.24)\end{array}$ \\
\hline$t=2$ & & $\begin{array}{l}-3.12 \\
(0.10)\end{array}$ & $\begin{array}{l}-2.58 \\
(0.10)\end{array}$ & $\begin{array}{l}-2.11 \\
(0.05)\end{array}$ & $\begin{array}{l}-1.14 \\
(0.08)\end{array}$ & $\begin{array}{c}0.07 \\
(0.23)\end{array}$ \\
\hline$t=3$ & & $\begin{array}{l}-3.33 \\
(0.10)\end{array}$ & $\begin{array}{l}-2.53 \\
(0.10)\end{array}$ & $\begin{array}{l}-2.12 \\
(0.06)\end{array}$ & $\begin{array}{l}-1.08 \\
(0.08)\end{array}$ & $\begin{array}{c}0.44 \\
(0.28)\end{array}$ \\
\hline$t=4$ & & $\begin{array}{l}-3.68 \\
(0.11)\end{array}$ & $\begin{array}{l}-2.83 \\
(0.11)\end{array}$ & $\begin{array}{l}-2.15 \\
(0.07)\end{array}$ & $\begin{array}{l}-1.02 \\
(0.09)\end{array}$ & $\begin{array}{c}0.31 \\
(0.25)\end{array}$ \\
\hline Mean i & impact & -3.25 & -2.61 & -2.12 & -1.09 & 0.15 \\
\hline Events & & 50,347 & 31,726 & 72,528 & 15,335 & 987 \\
\hline
\end{tabular}

Notes: This table shows estimates of the change in labor compensation as a share of sales (\%) within our C- to S-corporation switchers sample across different specifications. Pooled specification results are event study coefficients from figure A.1. "Omit t-2" omits event year $t=-2$ rather than event year $t=-1$ to address the concern that $t=-1$ data may reflect partial-year tax returns. Early and Late columns show results from years 2000-2006 and 2007-2012, respectively. Services shows average results across service-sector firms (2-digit NAICS industries 51, 52, 54, 56, 61, 62) from a pooled regression that interacts event-time indicators with industry indicators. Growth Ctrl shows results from a regression that includes the mean of firm-level sales growth prior to the switch interacted with event-time indicators as an additional set of controls. Columns (7)-(11) present our main event-study results (as shown in Figure 2A) across firm-size bins. Standard errors in parentheses. 
Table A.5: Adjusting the Labor Share under Different Specifications: Five-Year Averages

\begin{tabular}{|c|c|c|c|c|}
\hline & $\begin{array}{l}\text { 1978-1982 average } \\
\text { labor share }(\%)\end{array}$ & $\begin{array}{c}\text { 2013-2017 average } \\
\text { labor share }(\%)\end{array}$ & $\begin{array}{l}\text { Decline 1978-1982 } \\
\text { to 2013-2017 (pp) }\end{array}$ & $\begin{array}{c}\text { Share decline explained } \\
\text { by tax reporting (\%) }\end{array}$ \\
\hline \multicolumn{5}{|l|}{ A. Official estimate and main specification } \\
\hline Official BEA & 63.6 & 56.9 & 6.7 & \\
\hline Baseline adjustment & 63.6 & 58.7 & 4.9 & 26.3 \\
\hline \multicolumn{5}{|l|}{ B. Sensitivity analysis of recharacterized wage share } \\
\hline Use lower bound on switchers' confidence intervals & 63.6 & 58.8 & 4.8 & 28.1 \\
\hline Use upper bound on switchers' confidence intervals & 63.6 & 58.6 & 5.0 & 25.3 \\
\hline Use sales minus COGS denominator for switchers event study & 63.6 & 58.7 & 4.9 & 27.3 \\
\hline Treat large partnerships like mid-sized S-corporations & 63.6 & 59.1 & 4.5 & 33.2 \\
\hline \multicolumn{5}{|l|}{ C. Sensitivity analysis of GDP inflation correction } \\
\hline Keep corporate share of total VA constant at 1986 levels & 63.6 & 58.3 & 5.3 & 21.6 \\
\hline \multicolumn{5}{|l|}{ D. Joint sensitivity analysis with GDP inflation correction alternative } \\
\hline Use confidence interval lower bounds + Keep corp. share constant & 63.6 & 58.5 & 5.1 & 23.5 \\
\hline Use confidence interval upper bounds + Keep corp. share constant & 63.6 & 58.3 & 5.3 & 20.6 \\
\hline Treat large Pships like mid-sized S + Keep corp. share constant & 63.6 & 58.7 & 4.9 & 26.3 \\
\hline
\end{tabular}

Notes: This table conducts the same robustness exercises as in Table 2 except that it compares average labor shares over 1978-1982 and 2013-2017 rather than 1978 and 2017. 


\section{B Switcher Robustness}

Appendix Tables A.2 and A.3 provide sample summary statistics for the switchers analysis. We report statistics and the industry composition for both switchers and "stayers," defined as the population of C-corporations in 2016, which therefore excludes S- to C-corporation switches during our sample. Switchers are quite similar relative to stayers in terms of size and industry composition. Switchers are smaller on average though larger at the median, which reflects the fact that very large C-corporations elect to not to switch. Switchers face higher effective tax rates than stayers prior to switching, which supports our interpretation that the decision to switch reflects tax motives.

Appendix Figure A.2 plots event studies for the level of firm characteristics during switching events. The switching event appears to coincide with constant, modest growth, implying that firms that switch are likely to be firms that would benefit from lower taxes on total surplus in the future. Despite the firm growing in terms of revenues and the number of workers, switching coincides with a sharp decrease in labor payments. Tax rules appear to be the primary force that can explain the sharp and persistent decline in labor compensation and offsetting increase in tax-preferred profits. Note that identification of the effect we are studying does not rely on an assumption that switching events are randomly assigned. Instead, we assume that changes in labor compensation relative to contemporaneous firm sales around the switching event reflect the different tax incentives for S-corporations versus C-corporations. Appendix Table A.4 shows that including a control for pre-switch sales growth interacted with event-time indicators slightly strengthens our estimates.

\section{Robustness Details}

Table 2 explores the robustness of our adjusted corporate labor share. Panel A reports headline numbers: the official corporate labor share declined 5.0 percentage points from 1978 to 2017, while our adjusted corporate labor share declined only 3.4 percentage points, $31.9 \%$ smaller than in the official series.

Panels B and C report results from single deviations from our baseline adjustment. First, there is statistical imprecision in the recharacterized wages estimates $\bar{\gamma}_{b}$ from Figure $2 \mathrm{~A}$ that underlie our aggregate estimates. The first two rows use the $95 \%$ confidence interval lower bounds and the upper bounds on the bin-specific recharacterized wages estimates. The third row uses sales minus cost of goods sold rather than sales as the denominator in the eventstudy regressions and the recharacterized-wages calculation. Across these three analyses, we find that the tax-motivated growth in pass-throughs explains between $30.6 \%$ and $34.4 \%$ of 
the decline in the raw BEA corporate labor share.

Our partnership adjustment assumes that $0 \%$ of large partnership proprietors' income would be recharacterized wages, despite the fact that the partners of many large consultancies, law firms, accountancies, and financial services firms clearly provide human-capital services and are compensated by law via (nonwage) proprietor's income. The last row of Panel B sets the coefficient for the largest bin $\bar{\gamma}_{100 \mathrm{M}+}$ equal to the coefficient for the second

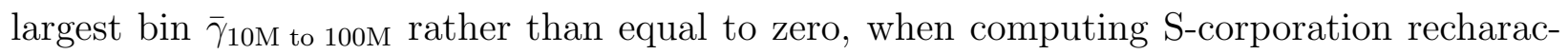
terized wages. In this case, tax-motivated growth in pass-throughs explains $40.4 \%$ of the decline in the raw series, highlighting the importance of mid-market and large firms in these adjustments.

Section B assumes that, in the absence of TRA86, all partnership activity would have grown at the same rate as GDP, so any excess partnership activity should be reallocated to C-corporations. Panel $\mathrm{C}$ makes a more conservative assumption: in the counterfactual, partnership activity would have grown fast enough to keep the corporate share of total value added constant at 1986 levels, rather than declining as it has in the official data. Specifically, we scale our measures of excess partnership activity such that corporate-plusexcess-partnership gross value added make up the same share of corporate-plus-noncorporate gross value added as the corporate sector did in 1986. This alternative assumption reallocates less partnership activity to the C-corporate sector, reducing the impact of the partnership adjustment. Under this assumption, tax-motivated growth in pass-throughs explains $26.8 \%$ of the decline in the corporate labor share.

Panel D conducts three double deviations from our baseline adjustment: the Panel C alternative plus one Panel B alternative. These analyses find that the tax-motivated growth in pass-throughs explains $25.5 \%-32.7 \%$ of the decline in the raw series.

We also conduct a perturbation analysis that illustrate the impact of the partnership owner-pay parameter on the results. ${ }^{14}$ We incrementally increase this parameter from $41.9 \%$ to $50 \%, 62 . \%$, and $75 \%$. For each alternative value, the share of the decline explained by tax reporting is $38.4 \%, 48.3 \%$, and $58.2 \%$, respectively. The latter value is aggressive, because the recharacterized-wage share of pass-through income is likely below the human-capital share of $75 \%$ estimated in Smith et al. (2019). Thus, the implied estimate can be interpreted as

\footnotetext{
${ }^{14}$ An alternative approach would impute wages to partners using observationally similar workers (Fleck et al., 2014). However, there is evidence that partners earn substantially more than observationally similar workers (see, e.g., Kaplan and Rauh (2010) or Azmat and Ferrer (2017) on the pay of law firm partners). Thus, such an approach would tend to understate recharacterized wages for the partnership sector; for example, BEA data imply the wage imputed for professional service workers would be less than $\$ 50$ in 2017. Ideally, one could also consider imputing partnership wages using owner pay for similar C-corporations. Unfortunately, we do not have complete data on the wage compensation of C-corporation owners, because firm-owner links are not available in the tax data for these firms.
} 
suggesting our approach can account for at most $58.2 \%$ of the decline in the raw series.

\section{Data Appendix}

This section describes the data sources for this paper, where we use the different data sources, and variable definitions. Section A outlines the series we use by data source. Section B reviews the data used in each exhibit, noting extrapolations.

\section{A Data by source}

\section{- National Income and Product Accounts (NIPA)}

- Table 1.1.5 "Gross Domestic Product: Annual" (line 1), retrieved 2021-03-06 via FRED using series code GDPA.

- Table 1.13: "National Income: Sole proprietors and partnerships" (line 19); "Consumption of Fixed Capital: Sole Proprietor and partnerships;" "Sole proprietors and partnerships: Compensation of employees" (line 20); and "Sole proprietors and partnerships: Proprietors' income with IVA and CCadj" (line 23). Retrieved 2021-03-06 via FRED using series codes A1641C1A027NBEA, A1615C1Q027SBEA, A1642C1A027NBEA, and A1645C1A027NBEA respectively.

- Table 1.14: "Gross value added of corporate business" (line 1); "Compensation of employees" (line 4). Retrieved 2020-09-04 via BEA graphic user interface (GUI).

- Table 7.14: "Posttabulation amendments and revisions" (line 3). Retrieved 202012-14 via BEA GUI.

- BEA GDP-by-Industry Accounts "Components of Value Added by Industry" table. Retrieved 2021-03-13 via BEA GUI.

\section{- Statistics of Income (SOI) public data:}

- Integrated Business Data (1980-2015). Retrieved on 2020-09-04 via https:// www.irs.gov/pub/irs-soi/15otidb1.xls.

- Table 1 "All Partnerships: Total Assets, Trade or Business Income and Deductions, Portfolio Income, Rental Income, and Total Net Income (Loss), by Industrial Group" 1993-2018. Retrieved on 2021-03-06 via https://www.irs.gov/ statistics/soi-tax-stats-partnership-statistics-by-sector-or-industry. 
- Table 2 "Sole-proprietorship Non-farm Income Statements" 1996-2018. Retrieved on 2021-03-06 via IRS webpage.

- Table 2.3 "Returns of Active Corporations, Other than Forms 1120S, 1120-REIT, and 1120-RIC" 2016 and 2017. Retrieved on 2021-03-06 via https://www.irs. gov/pub/irs-soi/16co23ccr.xlsx and https://www.irs.gov/pub/irs-soi/ $16 \mathrm{co} 23 \mathrm{ccr} . \mathrm{xlsx}$.

- Table 6.1 "Returns of Active Corporations, Form 1120S" 2016 and 2017. Retrieved on 2021-03-06 from https://www .irs .gov/pub/irs-soi/16co61ccr.xlsx and https://www.irs.gov/pub/irs-soi/17co61ccr.xlsx.

- United Nations System of National Accounts Table 4.8. Retrieved on 2020-0624 via the UN SNA GUI at http://data.un.org/Data. aspx?d=SNA\&f=group_code\% $3 a 408$.

- Restricted-use SOI corporate and partnerships samples, which we collapse to yield aggregates by industry (NAICS 2-, 3-, and 4-digit) and sales bin (in constant 2014 dollars).

- Other administrative data See subsection B for detailed descriptions

- Population of C- and S-corporation returns, 1996-2014

- Linked firm-owner tax returns for partnerships and S-corporations, 2001-2014, as in Smith et al. (2019), which we collapse to yield aggregates by industry and sales bin (in constant 2014 dollars).

- Replication data from Karabarbounis and Neiman (2014) (labor share by country) and Elsby, Hobijn and Şahin (2013) (supplement to BEA GDP-by-industry accounts).

\section{B Data by exhibit}

\section{Figure 1}

(a) Panel A uses "Gross value added of corporate business" (line 1) and "Compensation of employees" (line 4) from NIPA table 1.14, retrieved via BEA GUI.

(b) Panel B uses "National Income: Sole proprietorships and partnerships;" "Consumption of Fixed Capital: Sole Proprietorships and partnerships;" and GDP retrieved via FRED using series codes A1641C1A027NBEA,

A1615C1Q027SBEA, and GDPA, respectively. It also uses "Gross value added of corporate business" (line 1) from NIPA table 1.14, as in panel A. 
(c) Panel $C$ uses Net income of S-corporations, C-corporations, and partnerships from SOI Integrated Business Data.

(d) Panel D uses restricted-use data from the SOI corporate and partnerships samples. We calculate value added as the sum of $\mathrm{W}-2$ wages, non-wage compensation, interest paid, net depreciation, depletion, Domestic Prpoduction Activities Deduction, other deductions, and gross profits minus total deductions.

\section{Figure 2}

(a) Panel A uses the population of S- and C-corporation returns covering 1996-2016. For estimating event-study specifications, we narrow the sample to firms that switch from C- to S-corporation form from 2000 to 2012.

(b) Panels $B$ and $C$ use latest-year data from two sources. We take 2014 owner pay, defined as the sum of wages paid by firm and ordinary income, from our firmowner linked sample of S-corporations and partnerships. Sales (gross receipts) and value added, both from 2017, are from the SOI corporate and partnerships samples; value added is defined as in Figure 1D.

\section{Figure 3, Table 1, and Table 2}

(a) BEA Labor Share (Figure 3A and Table 1A) is the ratio of "Gross value added of corporate business" and "Compensation of employees" as in Figure 1A.

(b) S-corporation recharacterized wages are the product of total S-corporation receipts with average bin-specific recharacterized wage shares of receipts, weighted by each size bins' share of sales.

- Total S-corporation receipts From 1980 to 2015, we take S-corporation receipts from Integrated Business Data as in Figure 1C. For 2016 and 2017, we supplement the IBD aggregates with receipts from SOI table 6.1 "Returns of Active Corporations, Form 1120S."

- Size bin-specific S-corporation receipts are from collapses of the SOI corporate sample, as in Figure 2B and 2C, covering 1992-2017.

- Recharacterized wage shares of receipts are shown in Figure 2A.

We extrapolate S-corporation receipts backwards as a constant share of "Gross value added of corporate business" from NIPA table 1.14. We extrapolate the aggregate series (IBD and table 6.1) backwards from 1980 and the size bin-specific series backwards from 1992 . 
(c) Non-corporate employee compensation, profits, and other capital income Compensation and profits are "National income: Sole proprietorships and partnerships: Compensation of employees" and "National Income: Sole proprietorships and partnerships: Proprietors' income with IVA and CCadj" retrieved via FRED using series codes A1642C1A027NBEA and A1645C1A027NBEA, respectively, on 2021-03-06. Other capital income is the difference between Non-corporate gross value added as in Figure 1B and the sum of non-corporate employee compensation and profits.

(d) Partnership and sole proprietorship components of gross value added including employee compensation; proprietors' income; and other capital income are from sole proprietorship and partnership SOI income statements. Specifically, sole proprietorships data are from (non-farm) table 2 "Income Statements" retrieved on 2021-03-06. Partnerships data are from "Table 1: All Partnerships: Total Assets, Trade or Business Income and Deductions, Portfolio Income, Rental Income, and Total Net Income (Loss), by Industrial Group" retrieved on 2021-03-06. We construct components of GVA as described in section C. SOI proprietors' income is available from 1980 to 2017, and other SOI components of gross value added are available from 1996 to 2017. For years in which data are not available, we extrapolate backwards using shares from the earliest available year.

(e) W-2 wages paid to partners is from the firm-owner linked sample covering 20012014. We extrapolate backwards from 2001 and forwards from 2014 as a constant share of SOI partnership profits.

4. Appendix Figure A.1 uses event-study coefficients estimated within a subset of the population of $\mathrm{C}$ - and $\mathrm{S}$-corporation tax returns as in Figure 2. It also uses restricted-use SOI corporate sampele data to rank 2-digit industries by profits.

5. Appendix Figure A.3 plots NIPA corporate sector GVA from table 1.14; GDP retrieved via FRED (series code GDPA); and "Inorganic partnership GVA" as shown in Table 1.

6. Appendix Figure A.5 uses linked firm-owner data from Smith et al. (2019) for partnerships and from the SOI corporate sample for C- and S-corporations.

7. Appendix Figure A.6 uses data from the BEA GDP-by-industry accounts covering 1997-present, retrieved via the BEA GUI. We supplement these data with replication data from Elsby, Hobijn and Şahin (2013) which provides the BEA GDP-by-industry value added items from 1987-1997. 
8. Appendix Figure A.7 uses data from Karabarbounis and Neiman (2014), as well as from the UN System of National Accounts table 4.8, retrieved via the UN SNA GUI at http: //data.un.org/Data. aspx?d=SNA\&f=group_code\%3a408.

9. Appendix Figure A.8 uses the data underlying Figure $2 \mathrm{~B}$ and $2 \mathrm{C}$.

10. Appendix Table A.1 uses BEA GDP-by-industry data as in Figure A.6; collapses of the SOI corporate sample and firm-owner linked data as in Figure A.5; adjusted underlying series from table 1 ; and sector-specific event-study estimates partially shown in Figure A.1.

11. Appendix Tables A.2 and A.4 use the population of C- and S-corporate tax returns as in Figure $2 \mathrm{~A}$.

12. Appendix Table A.5 uses the same data as Table 2.

\section{Concept definitions in SOI data}

\section{Components of gross value added}

To calculate the partnership share of each component of gross value added (GVA), we construct GVA component analogs for both organizational forms in the SOI data as follows:

$$
\begin{aligned}
\text { Profits }_{\text {Sole prop, soI }} & \equiv \text { Net income } \\
\text { Compensation }_{\text {Sole prop, soI }} & \equiv \text { Cost of labor }+ \text { Contract labor }+ \\
& \text { Employee benefit programs }+ \\
& \text { Pension and profit-sharing plans }+ \\
& \text { Salaries and wages }
\end{aligned}
$$

Other capital income Sole prop, soI $\equiv$ Rent paid on machinery and equipment+

Rent paid on other business property + Taxes paid

Mortgage indebtedness + Depreciation+

Other interest paid on business indebtedness 


$$
\begin{aligned}
\text { Profits }_{\text {Pships, soI }} & \equiv \text { Net income } \\
\text { Compensation }_{\text {Pships, soI }} & \equiv \text { Cost of labor }+ \text { Salaries and wages }+ \\
& \text { Guaranteed payments to partners }+ \\
& \text { Pension and profit-sharing plans }+ \text { Employee benefit plans }
\end{aligned}
$$

Other capital income Pships, soI $_{\text {I }} \equiv$ Rent paid + Interest paid + Depreciation + Taxes paid

\section{Partnership share of gross value added components}

For each component of gross value added, we compute the partnership share of each component as one minus the sole proprietorship component. Specifically, for $c \in\{$ Compensation, Other capital income $\}$, we take:

$$
\text { Partnership share } c=1-\frac{c_{\text {Sole prop, SOI }}}{c_{\text {Sole prop, SOI }}+c_{\text {Pship, SOI }}} \text {. }
$$

For profits, we use a slightly different formula:

$$
\text { Partnership share profits }=1-\frac{\text { Profits }}{\text { Sole prop, SOI }} \frac{\text { Sole prop and pship profits }}{\text { NIPA 1.13 }} \text {. }
$$

where Sole prop and pship profits NIPA 1.13 $_{13}$ "National Income: Sole proprietorships and partnerships: Proprietors' income with IVA and CCadj" (retrieved via FRED using series code A1645C1A027NBEA). We choose this definition for the denominator to avoid doublecounting profits accruing to partnerships holding other partnerships (see, e.g., Pearce (2015) and Cooper et al. (2016)), though our results are not sensitive to this choice. 